PNL-9223

UC-603

\title{
Summary of Radiological Monitoring of Columbia River Water Along the Hanford Reach, 1980 Through 1989
}

R. L. Dirkes

February 1994

Prepared for

the U.S. Department of Energy

under Contract DE-AC06-76RLO 1830

Pacific Northwest Laboratory

Richland, Washington 99352 


\section{Summary}

Radionuclide concentrations in the Columbia River were well below applicable water quality standards in all cases during 1980 through 1989 . The potential dose to the public through this pathway is of little or no consequence with respect to health effects or applicable standards.

With the elimination of direct discharges of radiological contaminants to the river, the only radionuclides found in the river that were consistently influenced by Hanford (ground-water seepage) were tritium and iodine-129. Strontium-90 and uranium, also attributable to Hanford operations, were present in localized areas within the river near ground-water discharge points; however, these contaminants are quickly dispersed within the river to concentrations similar to background. 


\section{Acknowledgments}

The author recognizes the staff associated with the Surface Environmental Surveillance Project during the years 1980 through 1989 for their contributions to the Columbia River monitoring program. The author also wishes to express his appreciation to R. W. Hanf and R. K. Woodruff for technical peer review of the document; to the Sigma V Text Processing Team for word processing support; and to R. E. Lundgren and M. K. DeSmet for editing and report production. 


\section{Contents}

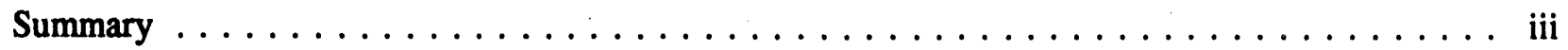

Acknowledgments $\ldots \ldots \ldots \ldots \ldots \ldots \ldots \ldots \ldots \ldots \ldots \ldots \ldots \ldots \ldots \ldots$





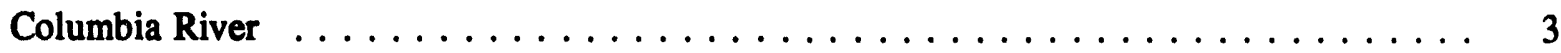

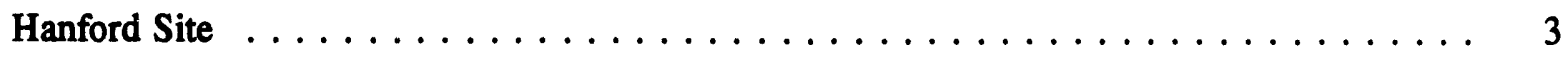

Surface-Water Surveillance $\ldots \ldots \ldots \ldots \ldots \ldots \ldots \ldots \ldots \ldots$

Columbia River Monitoring Program, 1980 Through $1989 \ldots \ldots \ldots \ldots$

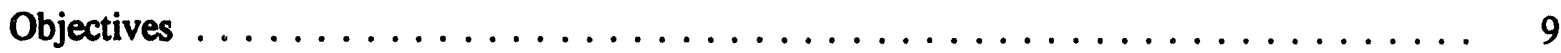

Rationale/Regulatory Requirements $\ldots \ldots \ldots \ldots \ldots \ldots \ldots$

Programmatic Rationale . . . . . . . . . . . . . . . . . . 9

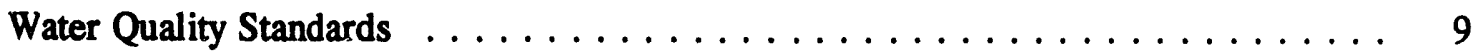

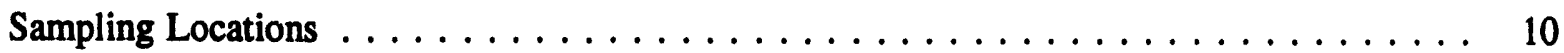



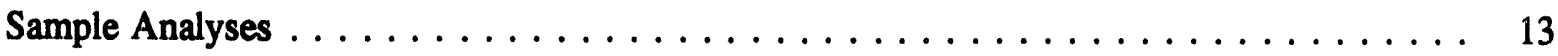

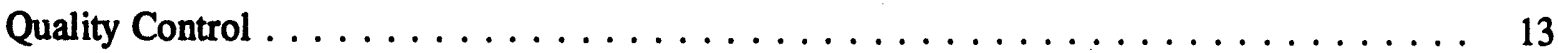

Special Studies $\ldots \ldots \ldots \ldots \ldots \ldots \ldots \ldots \ldots \ldots \ldots \ldots \ldots \ldots \ldots \ldots \ldots$

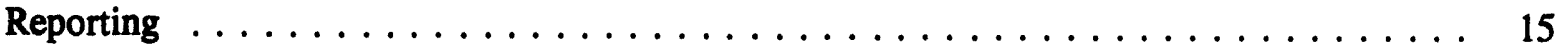

Results and Discussion $\ldots \ldots \ldots \ldots \ldots \ldots \ldots \ldots \ldots \ldots \ldots$

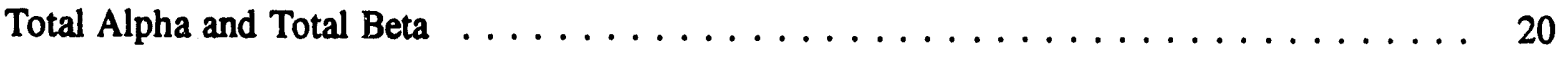

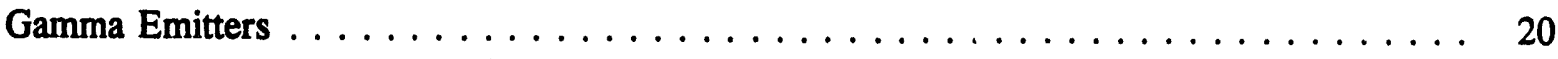

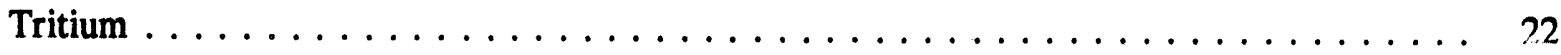




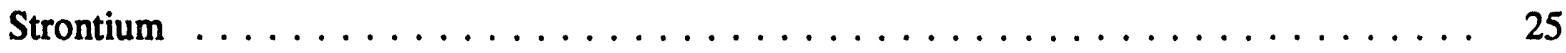

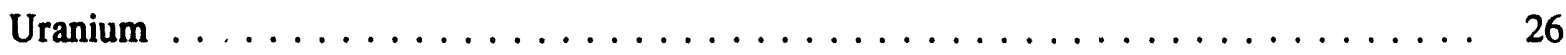

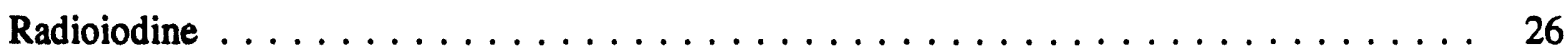

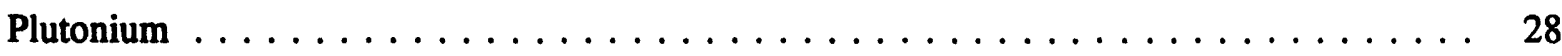

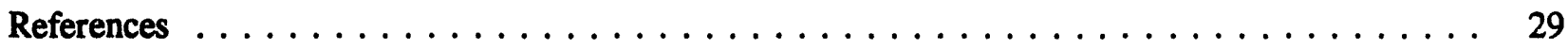

Appendix - Summaries of Columbia River Water Sampling Results $\ldots \ldots \ldots \ldots \ldots$. . . . A.1 


\section{Figures}

1 U.S. Department of Energy's Hanford Site $\ldots \ldots \ldots \ldots \ldots \ldots \ldots \ldots$

2 Columbia River Water Sampling Locations, 1980 Through $1989 \ldots \ldots \ldots \ldots$

3 Annual Average Total Alpha Concentrations in Columbia River Water at Priest Rapids Dam, the 300 Area, and the Richland Pumphouse, 1980 Through 1989 . . . . . . . . . . 21

4 Annual Average Total Beta Concentrations in Columbia River Water at Priest Rapids Dam, the 300 Area, and the Richland Pumphouse, 1980 Through $1989 \ldots \ldots \ldots \ldots$. . . . 22

5 Annual Average Tritium ( $\left.{ }^{3} \mathrm{H}\right)$ Concentrations in Columbia River Water at Priest Rapids Dam, the 300 Area, and the Richland Pumphouse, 1980 Through $1989 \ldots \ldots \ldots \ldots$

6 Difference in Annual Average Tritium ( $\mathrm{CH}$ ) Concentrations in Columbia River Water from Priest Rapids Dam and the Richland Pumphouse, 1980 Through 1989 . . . . . . . . . 24

7 Annual Average Strontium-90 ( $\left.{ }^{90} \mathrm{Sr}\right)$ Concentrations in Columbia River Water at Priest Rapids Dam, the 300 Area, and the Richland Pumphouse, 1980 Through 1989 . . . . . . . 25

8 Annual Average Uranium Concentrations in Columbia River Water at Priest Rapids Dam, the 300 Area, and the Richland Pumphouse, 1980 Through $1989 \ldots \ldots \ldots$. . . . . . 27

9 Annual Average Iodine-129 $\left({ }^{129} \mathrm{I}\right)$ Concentrations in Columbia River Water at Priest Rapids Dam, the 300 Area, and the Richland Pumphouse, 1980 Through 1989 . . . . . . . 28

\section{Tables}

1 SESP Columbia River Water Monitoring Locations, 1980 Through $1989 \ldots \ldots$

2 Annual Average Columbia River Discharges at Priest Rapids Dam, 1980 Through 1989 . . 18

3 Comparison of Selected Radionuclides in Columbia River Water at Priest Rapids Dam, the Richland Pumphouse, and the 300 Area, 1980 Through 1989 . . . . . . . . . . . . . 19 


\section{Introduction}

The Surface Environmental Surveillance Project (SESP) is conducted by the Pacific Northwest Laboratory (PNL) for the U.S. Department of Energy (DOE) at the Hanford Site in southeastern Washington State. The Columbia River monitoring program, conducted as part of the SESP, provides a historical record of contaminant concentrations in the river attributable to natural causes, worldwide fallout, and operations conducted at the Hanford Site. In addition to ongoing monitoring, special studies are conducted periodically to enhance the understanding of the transport and fate of contaminants in the river. Special studies are also conducted to provide information relative to specific areas of interest or concern.

The Columbia River monitoring program includes sampling of river water, river sediment, riverbank springs entering the river, and various types of aquatic biota found in or along the river. These samples are analyzed for radiological constituents and a wide range of chemical parameters. This report describes the water sampling component of the overall Columbia River monitoring program conducted during the years 1980 through 1989 and summarizes the radiological results generated through the program during this time period. Special studies performed through the SESP during the 1980s that focused on radionuclides in river water are also described briefly and results of these studies included as appropriate.

Results of the SESP Columbia River monitoring program are typically documented on an annual basis through the Hanford Site environmental reports or as topical reports documenting special studies. Neither of these avenues generally provides an evaluation of the contaminant levels in the Columbia River over time. This report, covering a decade of monitoring results, provides information about long-term trends in radioactive contaminant concentrations in the river and enhances the evaluation of potential impacts attributable to Hanford operations by providing statistical analyses of larger data sets.

The report provides background information about the hydrological characteristics of the Columbia River, past Hanford operations including releases to the Columbia River, and a brief history of river monitoring activities. The introductory material is followed by a description of the Columbia River monitoring program during the 1980 s and finally discussion of the monitoring program results. Data, which are discussed and displayed graphically in the text, are presented in tabular form in the appendix. 


\section{Background Information}

This section provides background information on the Columbia River, Hanford Site, and surfacewater surveillance at the Site.

\section{Columbia River}

The Columbia River, which originates in the mountains of eastern British Columbia, Canada, flows through the northern portion of the Hanford Site and forms part of the Site's eastern boundary (Figure 1). The Hanford Reach of the Columbia River extends from Priest Rapids Dam upstream from the Site to the head of the Lake Wallula (created by McNary Dam) near Richland (downstream from the Site). This stretch of the Columbia River is the last upstream from Bonneville Dam within the United States that remains unimpounded.

Flows through the Reach fluctuate significantly and are dictated primarily by operating constraints at Priest Rapids Dam. Annual average flows at Priest Rapids Dam over the last 68 years have averaged approximately 120,000 cubic feet per second (cfs) (McGavock et al. 1987). Daily average flows range from $36,000 \mathrm{cfs}$ to $250,000 \mathrm{cfs}$. Monthly mean flows typically peak from April through June and are lowest from September through October.

The Washington State Department of Ecology (WDOE) has designated the Columbia River along this stretch as Class A, Excellent (WDOE 1992). Water use guidelines are provided and water quality standards established for this class designation. Class A waters are to be suitable for essentially all uses, including raw drinking water, recreation, and wildlife habitat.

The primary uses of the Columbia River along the Hanford Reach include the generation of hydroelectric power and extensive irrigation of nearby farmland. Several communities located on the Columbia River rely on the river as their source of drinking water. Water from the Columbia River along the Hanford Reach is also used at the Hanford Site as a source of drinking water by several onsite facilities and for industrial uses. In addition, the Columbia is used extensively for recreational activities such as fishing, hunting, boating, sailboarding, waterskiing, and swimming.

Several state and federal wildlife refuges have been established along the Columbia River adjacent to and downstream of the Hanford Site. The Hanford Reach is the spawning ground for the second largest naturally reproducing fall chinook salmon run in the continental United States and also supports a substantial steelhead fishery (Dauble and Watson 1990).

\section{Hanford Site}

The Hanford Site, established in 1943, occupies an area of approximately 560 square miles. The Site lies approximately 170 miles southeast of Seattle, Washington; 125 miles southwest of Spokane, 
Washington; and 200 miles northeast of Portland, Oregon (Figure 1). The Hanford Site environment is described in detail in Hanford Site National Environmental Policy Act (NEPA) Characterization (Cushing 1988).

The Hanford Site was established to design, build, and operate nuclear reactors and chemical separations facilities for the production of special nuclear materials. Past operations at the Hanford Site are discussed in detail in Final Environmental Statement, Waste Management Operations. Hanford Reservation. Richland. Washington (ERDA 1975).

Nine production reactors have operated along the banks of the Columbia since the Site was established. Eight of these reactors used once-through-cooling systems, which resulted in the release of heated water, corrosion-inhibiting chemicals, and radionuclides, primarily activation products, directly into the river. The ninth reactor, $\mathbf{N}$ Reactor, used a closed-loop-cooling system that resulted in a significant amount of heat being discharged directly into the Columbia River but with very little radioactivity associated with the effluent. With the shutdown of the once-through-cooling system reactors from 1965 to 1971, direct discharges of contaminants into the Columbia River were virtually eliminated, resulting in a tremendous decrease in the amount of radioactivity released to the river (Becker 1990; Cushing et al. 1981).

In addition to liquid discharges directly to the river, large volumes of wastewater were generated and discharged to the ground as a result of Hanford operations. The disposal of this liquid effluent to the ground has had a considerable impact on the unconfined aquifer beneath the Site. The movement of ground water and the associated radiological and nonradiological contaminants have changed over time as a result of the variation in both the volumes and composition of the wastewater. In general, the predominant flow pattern of Hanford ground water is from the recharge areas in the west to the discharge areas (primarily the Columbia River) in the east (Freshley and Graham 1988; Woodruff et al. 1992). Contaminants are known to be entering the river via riverbank springs along the Hanford Reach (Dirkes 1990; DOE-RL 1992; Manley 1992; McCormack and Carlile 1984; Peterson and Johnson 1992).

\section{Surface-Water Surveillance}

The Columbia River has been monitored at the Hanford Site since 1945, shortly after the startup of the original plutonium production reactors. Samples have been collected from several locations over the years, including stations upstream of the Site, along the Hanford Reach, and downstream of the Site. Currently, the SESP is responsible for the routine monitoring of Hanford Site surface waters, including the Columbia River.

Originally, the primary objective of river surveillance efforts was to detect reactor-created radioisotopes rather than to quantify the radionuclides or perform dose assessments. Dose rates were measured at several locations downstream of the reactor outfalls; these measurements indicated that radiation levels dropped rapidly as the effluents were dispersed within the river. Sampling of the Columbia River began shortly after reactor startup to serve the need to not only detect but to measure the quantity of radionuclides in the river water and evaluate the resultant exposures. 


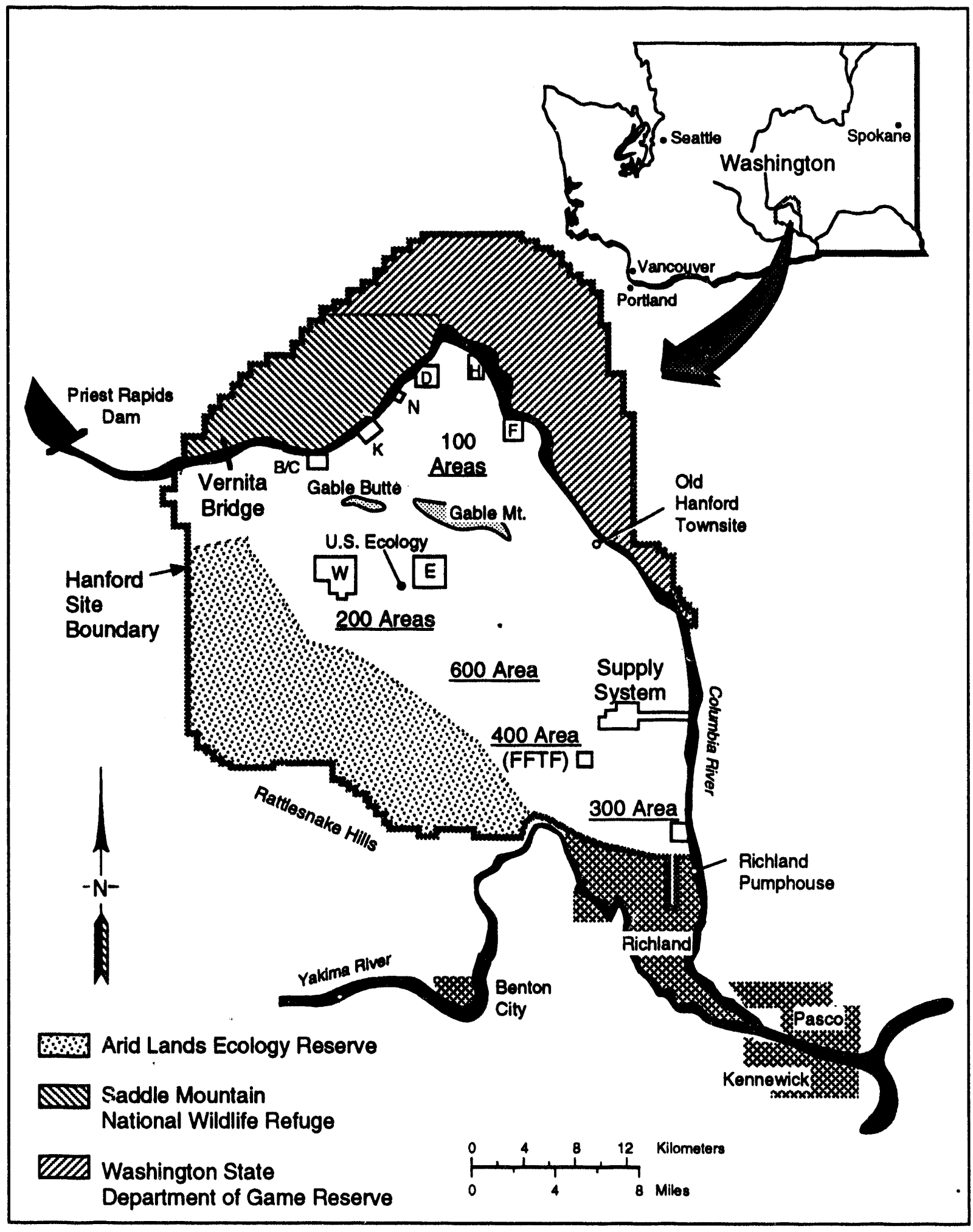

S9304026.2

Figure 1. U.S. Department of Energy's Hanford Site 
During the late 1940s and 1950s the Columbia River monitoring program expanded significantly, providing a large amount of data from many locations. Sample stations were established upstream of the Site, along the Site, and extended downstream as far as the Portland, Oregon/Vancouver, Washington area. In addition, numerous special studies were conducted during the years of peak liquid effluent discharges to observe the channeling of reactor effluent within the river. These studies were conducted to better understand the dispersion characteristics of the river and to enhance the interpretation of data obtained from single-point monitoring stations located on the river (Backman 1962; Haney 1957; Honstead 1954; Honstead 1957; Honstead et al. 1951; Norton 1957; Soldat 1962; Sonnichsen et al. 1970).

Sample analysis during the early years consisted primarily of total beta measurements. Analytical capabilities were in their infancy during the early years of the Hanford site and specific radionuclide analyses were not yet available. Methods were constantly improving throughout the late 1940 s and early 1950s. With the introduction of gamma energy spectroscopy in 1957, it became practical to obtain isotopic analyses of river water samples on a routine basis.

During the late 1950 s, the Columbia River monitoring program was streamlined to generate the optimum amount and type of river water data to evaluate the potential radiation doses received by the public living near and using the Columbia River. Routine river water sampling indicated the burden of radioactive materials added to the river as a result of Hanford operations. In addition, the monitoring program provided insight on seasonal changes and long-term trends in the concentrations of radionuclides resulting, in part, from changes in operating procedures and practices. Continuous monitoring also provided a mechanism for detecting and evaluating the effects of abnormal releases.

The Columbia River monitoring program that was in place during the early 1960 s served as the predecessor of today's SESP river monitoring program. Sampling sites were selected to provide data intended to meet specific needs. Upstream locations were established to determine background radionuclide concentrations for use in assessing any contribution from Hanford effluents. The first downstream points of water withdrawal for use as public drinking water supplies were also established as routine sample locations. Points farther downstream such as Bonneville Dam and Vancouver served as indicators of the amount of radioactivity being either discharged via the river into the Pacific Ocean or taken up within the river environment. Sampling at these remote locations was discontinued as the concentrations of radionuclides diminished to undetectable levels following the shutdown of the reactors.

Ultimately, the Columbia River monitoring network was streamlined to a few locations that provided the optimum amount and type of information to estimate potential offsite impacts. The primary locations were chosen to represent background conditions upstream of Site operations (Priest Rapids Dam) and to establish an upper estimate of the amount of radioactivity in the water supply of any population using Columbia River water by sampling at the first downstream point of withdrawal (Richland Pumphouse). These locations continue to serve as the primary sampling locations on the Columbia River for the SESP. Samples of Columbia River water were also collected.periodically at other locations in conjunction with special studies conducted during the 1980s.

Sampling methods and equipment have changed over the years.. Grab samples were normally collected during the very early years. Composite sampling was used later in the program to provide better estimates of the average radionuclide concentrations in the river at a given location over time. Special 
continuous sampling systems (filter/resin) were put into service to increase the sample size sufficiently to detect specific radionuclides at very low concentrations and to discriminate between the dissolved and particulate fractions (Fix and Robertson 1976). In addition to improvements in sample collection methods, analytical procedures have undergone numerous upgrades to enhance the analytical sensitivities and detect low levels of radionuclides in river water.

Results of environmental surveillance activities, including Columbia River monitoring, were reported in quarterly status reports from 1946 through 1957 . In 1958, the practice of issuing annual environmental monitoring reports was initiated, providing improved documentation of the findings of the river monitoring program (Andersen 1959). The latest of these reports, Hanford Site Environmental Report for 1992, was issued in 1993 (Woodruff et al. 1993).

In addition to annual reports, topical reports document radiological monitoring results generated during special studies (Dirkes 1990; Dirkes 1993; McCormack and Carlile 1984). The chemical water quality of the Columbia River and bioenvironmental studies conducted on the river during the years of Hanford operations have also been well documented (Becker 1990; Becker and Gray 1992; Becker and Neitzel 1992; Dirkes et al. 1993). Historical river monitoring activities and results, primarily for the years during and just after reactor operations, have been summarized recently as part of ongoing studies outside of the SESP such as the Hanford Environmental Dose Reconstruction Project (Walters et al. 1992) and as part of ongoing investigations conducted under the Comprehensive Environmental Response, Compensation, and Liability Act (Dirkes 1992).

The levels of radioactive materials in Columbia River water decreased dramatically following the shutdown of the last single-pass-cooling production reactor during 1971 (Bramson and Corley 1972). Concentrations dropped to levels typically expected as a result of fallout from atmospheric testing of nuclear weapons. Since then, radionuclide concentrations in the Columbia River have remained extremely low. Currently, most radionuclides are not measurable without the use of special collection and/or analytical techniques. 


\section{Columbia River Monitoring Program, 1980 Through 1989}

This section discusses the objectives, rationale and regulatory requirements, sampling locations, sample collection, sample analyses, quality control, special studies, and reporting of the Columbia River monitoring program from 1980 through 1989.

\section{Objectives}

The objectives of the Columbia River monitoring program included:

- characterize contaminants in the surface-water environment

- assess impacts of Hanford operations on the water quality of the Columbia River

- determine compliance status with respect to applicable water quality standards

- identify significant changes in concentrations of contaminants (radiological and chemical) in surface water

- verify adequacy of effluent monitoring and controls

- provide public reassurance that risks associated with the use of the Columbia River are low and being evaluated on a continuous basis.

\section{Rationale/Regulatory Requirements}

\section{Programmatic Rationale}

The basis for the design of the Columbia River monitoring program during the 1980 s was provided in A Guide For: Environmental Radiological Surveillance at U.S. Department of Energy Installations (Corley et al. 1981). In addition, other environmental monitoring guides and references were available and considered in the development of the Columbia River monitoring program at the Hanford Site. Similarly, references and guidance specific to water quality monitoring and water sample collection have been used in the development of sampling protocols.

\section{Water Quality Standards}

The state of Washington has established water quality standards for various classifications of its surface waters. As discussed earlier, the Hanford Reach of the Columbia River has been designated as Class A, Excellent. During the 1980s, water quality standards for the surface waters of the state of Washington were contained in Chapter 173-201 of the Washington Administrative Code (WDOE 1982). These standards specify that radioactive materials for all classes of water shall in no case exceed the U.S. Environmental Protection Agency (EPA) Drinking Water Regulations 
(40 CFR 141). As such, radionuclide concentrations in the Columbia River are compared to the EPA drinking water standards (DWS) throughout the discussion of the Columbia River monitoring results.

\section{Sampling Locations}

Columbia River water samples were collected during the 1980s at locations identified on Figure 2. Samples were routinely collected upstream of Hanford facilities at Priest Rapids Dam to provide background data from locations unaffected by Site operations. Samples were collected from the 300 Area water intake and the Richland Pumphouse, downstream of the Hanford Site, to identify any increase in contaminant concentrations at these locations from Hanford operations. Both the 300 Area and the Richland Pumphouse sampling locations are at intakes for drinking water supply systems. These locations provide an upper estimate of the amount of radioactive material in the water supply (drinking or irrigation) of the potentially affected population group(s) downstream of the Hanford Site (DOE 1991).

Priest Rapids Dam is located approximately $8 \mathrm{~km}$ upstream of the Site boundary and $20 \mathrm{~km}$ upstream of the 100-B Area. The water sampler at Priest Rapids Dam is positioned approximately midstream within the dam and collects water from the reservoir behind the dam. Samples are also collected from the Benton County shoreline near the Vernita Bridge for analysis of nonradiological constituents.

The 300 Area water intake is located near the southern boundary of the Site at the point of withdrawal for the 300 Area drinking and process water supply. This location is of historical importance because it has been in use since the early days of Hanford operations. The sampling system intake is located in the water supply system intake structure on the Benton County shoreline of the river. Concentrations of ${ }^{3} \mathrm{H},{ }^{129} \mathrm{I}$, and uranium observed here are influenced by ground-water seepage along the Hanford Reach shoreline.

The Richland Pumphouse is the first downstream point of river water withdrawal for a public drinking water supply. The Richland Pumphouse is located approximately $3 \mathrm{~km}$ downstream of the Site boundary and about $5 \mathrm{~km}$ downstream of the most downstream Hanford facility effluent discharge. The water sampling intake is located within the city of Richland drinking water supply intake on the Berton County shoreline, approximately $9 \mathrm{~m}$ into the river. Historical environmental monitoring reports indicate this to be the drinking water supply having the maximum radionuclide concentrations downstream of the Hanford Site (Corley 1970, 1973; Corley and Woolridge 1969; Fisher and Wilson 1970; Foster 1966; Foster and Wilson 1964, 1965; Honstead 1967).

During 1980, samples were collected from the 100-B Area water intake forebay. At the time, this location was considered to be upstream of any influence from Hanford operations. However, it was determined that there was potential for seepage of contaminated ground water into the river upstream of this sampling location, and the composite river sampling system was relocated to Priest Rapids Dam, consistent with the existing continuous filter/resin system already operating at this location.

Columbia River water samples were also collected just upstream of the old Hanford Townsite during 1982. Sampling at this location was conducted in an effort to verify the source of ${ }^{129} \mathrm{~T}$ observed 


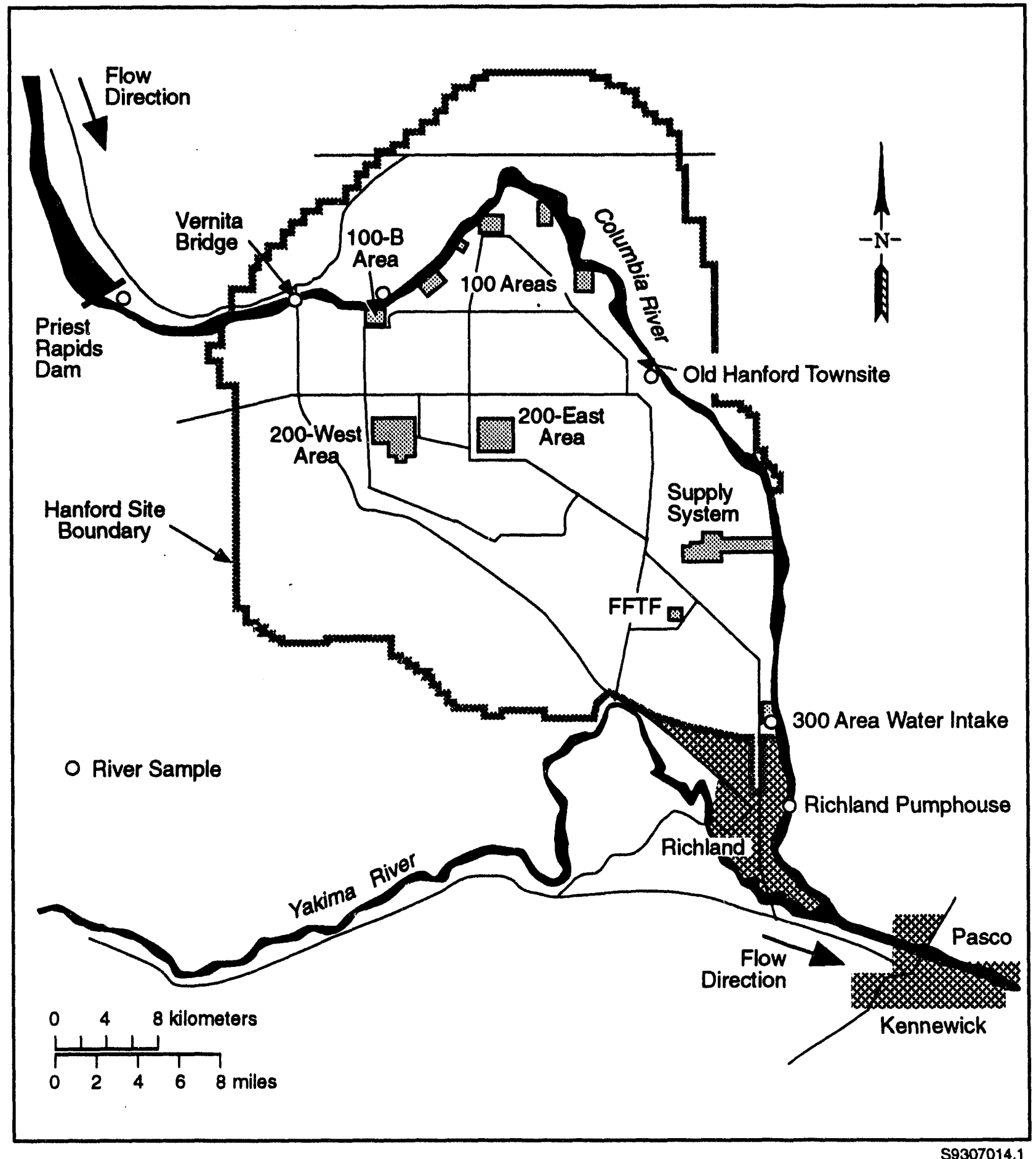

Figure 2. Columbia River Water Sampling Locations, 1980 Through 1989 
in water samples from the 300 Area. Results from this location also confirmed that ${ }^{3} \mathrm{H}$ was entering the river at locations upstream of the old Hanford Townsite via the 100 Areas ground-water seepage, as well as downstream via the 200 Area ground-water seepage.

In addition to the sampling systems identified above, river samples were collected on a limited basis at other locations along the Hanford Reach as part of special studies focused on the riverbank springs (Dirkes 1990; McCormack and Carlile 1984) and as part of the Drinking Water Monitoring Project (DWMP). Locations typically sampled under the DWMP include the 100-B, 100-D, 100-K and 100-N Areas. The DWMP sample results were reported in a series of annual reports published by the Hanford Environmental Health Foundation, titled Hanford Sanitary Water Ouality Surveillance for Calendar Year (1981 - 1990) (Maas 1981, 1982, 1983, 1984, 1985; Somers 1986, 1987, 1988, 1989; Thurman 1990).

Transect sampling at the Richland Pumphouse location was conducted during 1987 and 1988 to define the relationship between radionuclide concentrations in the sampling system and the average river concentrations. The point of entry into the river of the contaminated ground-water plume from the 200 Areas was nearing the downstream sampling locations during the 1980 s, as documented by the ground-water monitoring project (Evans et al. 1992). Therefore, an evaluation of the representativeness of these sampling locations was warranted. Samples along the transects were collected at multiple depths and at several points (up to 20) across the river. Initial transect sampling was used to identify those contaminants that were measurable in the river and that may have been influenced by the contaminated ground-water plume. Past transect sampling near this location had indicated the distribution of total beta activity to be slightly elevated near the Benton County shoreline (Soldat 1962).

\section{Sample Collection}

During the 1980s, the selection of sampling methods and equipment was predicated on the expected contaminant concentration, the potential for fluctuations in contaminant concentrations, the variability of the contaminant release into the receiving water, the physical and chemical characteristics of the contaminant of interest, and the potential for significant environmental or human impact. Three types of water samples were routinely collected from the Columbia River for radiological analyses during the 1980s. Grab samples were typically used when the water characteristics were relatively stable; information on minimum, maximum, and variability (time and spatial) was desired; or the parameters to be analyzed were likely to change during sample storage. Composite samples were used to determine average concentrations over time at a single location and provide certainty that contaminants did not flow by the sampling location between sampling dates. Continuous samples were also used in determining average concentrations, providing the very large volumes of water needed to detect those contaminants present at extremely low concentrations.

Composite sampling systems were operated at Priest Rapids Dam, the 300 Area water intake, and the Richland Pumphouse throughout the 1980s. A composite sampling system was also used at the 100-B Area location during 1980. The composite samplers at Priest Rapids Dam and the Richland Pumphouse consisted of timer-activated units that periodically collected water from a continuously flowing substream of Columbia River water into a 10-L container. The sampling sequence included a pre- and post-subsample air purge of the sampling line to avoid cross contamination between the 
individual sample aliquots. The cycle was repeated throughout a set sampling period, typically 1 week at Priest Rapids Dam and the Richland Pumphouse, such that approximately $55 \mathrm{~mL}$ of water are collected every hour. The 10-L sample container was changed every week, and the sample taken to the laboratory, where water from each location was composited over a 4-week period, resulting in a total sample size of approximately $40 \mathrm{~L}$. The system at the 300 Area was similar, except that sample aliquots were collected approximately every 4 hours, and samples were collected monthly and composited for quarterly analysis.

Continuous sampling systems were operated at Priest Rapids Dam and the 300 Area water intake throughout 1980 through 1989. A continuous system was established at the Richland Pumphouse in 1987. The continuously flowing systems were used to separate radionuclides from the river water before analysis. A large volume of water was required to allow the extremely low concentrations of some radionuclides to be detected. River water was pumped through the collection system at a rate of approximately $50 \mathrm{~mL} / \mathrm{min}$, resulting in a total sample volume of about $1000 \mathrm{~L}$ during each 2-week sampling period. Suspended particulates greater than $0.45 \mu \mathrm{m}$ diameter were removed on a series of filters, and soluble radionuclides, except ${ }^{3} \mathrm{H}$, were collected on a mixed-bed, ion-exchange resin column. The filters and ion-exchange resin were changed every 2 weeks, composited by location on a monthly basis, and analyzed for gamma-emitting radionuclides. The filters and resin from each location were then composited by media on a quarterly basis for specific radionuclide analyses.

\section{Sample Analyses}

Radionuclides of interest were selected based on their importance in determining water quality, verifying effluent control and effluent monitoring systems, determining compliance with applicable standards, and contributing to the potential exposure received by the public. Columbia River water samples were analyzed for those constituents that, as determined by pathway analyses, represented a significant fraction of the potential dose from the water pathway. In addition, contaminants of public concern were included in the analytical scheme. In general, analyses included those contaminants known or suspected to be present in the river water, in ground-water seepage entering the river, or in ground water near the river. In those cases where constituents had been documented to be consistently below measurable levels, the analyses were removed from subsequent sampling plans.

Radiological analyses on grab and composite water samples collected from the Columbia River during 1980 through 1989 included total alpha, total beta, gamma scan, ${ }^{3} \mathrm{H},{ }^{89} \mathrm{Sr},{ }^{90} \mathrm{Sr}$, and uranium. Total alpha and total beta measurements provided a general indication of the radioactivity present in river water. Gamma scans provided the ability to monitor for numerous specific gamma-emitting radionuclides including ${ }^{60} \mathrm{Co},{ }^{65} \mathrm{Zn},{ }^{95} \mathrm{ZrNb},{ }^{106} \mathrm{Ru},{ }^{125} \mathrm{Sb},{ }^{134} \mathrm{Cs},{ }^{137} \mathrm{Cs},{ }^{144} \mathrm{CePr},{ }^{154} \mathrm{Eu}$, and ${ }^{155} \mathrm{Eu}$, as well as others. The continuous filter/resin samples were analyzed primarily for ${ }^{129} \mathrm{I},{ }^{238} \mathrm{Pu}$, and ${ }^{239}$, ${ }^{240} \mathrm{Pu}$. Gamma scans were also performed on the filters and resins that were routinely collected.

\section{Quality Control}

The SESP was conducted as defined in project management plans (PMPs) that were reviewed, revised, and approved on an annual basis during 1980 through 1989. 
A comprehensive quality assurance program, PNL-MA-70 Quality Assurance Plan No. EES-52, Rev. 0 , including various quality control practices, was maintained to ensure the quality of data collected through the SESP. The design basis and rationale for the SESP and detailed descriptions of the various monitoring activities conducted under the SESP are documented in the Hanford Site Environmental Monitoring Plan, (DOE-RL 1991). The SESP is managed as documented through Project Management Plan. Hanford Site Surface Environmental Surveillance, which is issued under the Office of Health and Environment. Training requirements that are specific to the SESP are identified and documented through the SESP Training Program. Sample collection and field measurement procedures are documented in PNL-MA-580 (Hanf and Dirkes 1992). Sampling station locations are documented in the SESP Sample Locations Manual. The SESP Project and Data Management System (PDMS) generates the environmental monitoring sampling schedule, manages the records on sample and result accountability, and provides monitoring data storage.

Columbia River water samples were collected by dedicated staff trained to conduct sampling according to approved and documented procedures. Samples were analyzed using documented standard analytical procedures. Analytical data quality was verified by a continuing program of internal laboratory quality control, participation in interlaboratory cross checks, replicate sampling and analysis, submittal of blind standard samples and blanks, and splitting samples with other radiochemical laboratories.

Sufficient Columbia River monitoring data were obtained to minimize reliance on a limited amount of sampling results. New data collected were compared with both recent results and historical data to ensure that deviations from previous conditions were identified and promptly evaluated. Sampling results were also compared with anomalous data limits established within the computerized database to screen incoming data.

\section{Special Studies}

Several special studies were conducted under the SESP during the 1980s that were designed to address specific issues or provide environmental data for a specific media or location. The data generated through these special studies better characterized the levels and fate of contaminants in the environment, provided a better understanding of environmental monitoring data, and allowed for a more accurate interpretation of that data. Special studies performed during this time addressing contaminants in Columbia River water included:

- a $1982 / 1983$ investigation of ground-water seepage (contaminants of concern were nitrate, ${ }^{3} \mathrm{H}$, and uranium) into the river along the entire Hanford Reach

- a 1982 river sampling activity just upstream of the Hanford Site to determine the source of ${ }^{129} \mathrm{I}$ entering the river along the Hanford Reach

- a $1987 / 1988$ investigation of the distribution of ${ }^{3} \mathrm{H}$ in the river at the Richland Pumphouse 
- a 1988 study of the riverbank springs, which focused on locations with known ground-water contaminants but expanded the list of contaminants of concern to include an extensive list of radiological and chemical constituents of potential Hanford origin.

\section{Reporting}

Results of the routine Columbia River monitoring program are documented in the annual Hanford Site environmental reports for 1980 through 1989 as listed below:

- Environmental Surveillance at Hanford for CY-1980 (Sula and Blumer 1981)

- Environmental Surveillance at Hanford for CY-1981 (Sula et al. 1982)

- Environmental Surveillance at Hanford for CY-1982 (Sula et al. 1983)

- Environmental Surveillance at Hanford for CY-1983 (Price et al. 1984)

- Environmental Monitoring at Hanford for 1984 (Price et al. 1985)

- Environmental Monitoring at Hanford for 1985 (Price 1986)

- Environmental Monitoring at Hanford for 1986 (PNL 1987)

- Environmental Monitoring at Hanford for 1987 (Jaquish and Mitchell 1988)

- Environmental Monitoring at Hanford for 1988 (Jaquish and Bryce 1989)

- Environmental Monitoring at Hanford for 1989 (Jaquish and Bryce 1990)

In addition to annual reports, topical reports documented radiological monitoring results generated during special studies conducted during this time period (Dirkes 1990; Dirkes 1993; McCormack and Carlile 1984). The chemical water quality of the Columbia River and bioenvironmental studies conducted on the river during the years of Hanford operations have also been summarized outside of the annual reports (Becker 1990; Becker and Gray 1992; Becker and Neitzel 1992; Dirkes et al. 1993). 


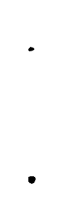




\section{Results and Discussion}

The Columbia River monitoring program conducted during the years 1980 through 1989 by the SESP is summarized in Table 1. The table provides the sampling locations, sample type, and the years the systems were operated at these locations. The locations and sample types, as well as the analyses, were described in detail earlier in this report.

The flowrate of the Columbia River through the Hanford Reach was measured at Priest Rapids Dam by the U.S. Geologic Survey during the 1980s. In general, flows throughout the period of interest were typical. Daily average flows ranged from $38,500 \mathrm{cfs}$ to $285,000 \mathrm{cfs}$ during the 10 -year period. Monthly mean flows peaked during April through June and were lowest in September or October. Annual average flowrates for the years 1980 through 1989 are presented in Table 2. Annual average flows during 1981, 1982, and 1983 were above the long-term average of 120,000 cfs, while 1980 and 1984 through 1989 annual averages were slightly lower than normal.

Results of the radiological analyses of Columbia River water samples collected at Priest Rapids Dam, the 100-B Area, the old Hanford Townsite, the 300 Area, and the Richland Pumphouse during the years 1980 through 1989 are summarized in Tables A.1 through A.8, Appendix, respectively. Because of the magnitude of data that exist relative to radionuclide concentrations in the Columbia River, Tables A.1 through A.8 contain only those radionuclides that were consistently present at concentrations greater than the analytical detection limit or that were commonly associated with Hanford operations. Those radionuclides that were detected in $50 \%$ or greater of the samples during the years 1980 through 1989 were considered to be consistently present. All sample results generated by the routine Columbia River monitoring program during these years are contained in the SESP database (Project and Data Management System).

Data summaries, Tables A.1 through A.8, include the constituent of concern, the number of samples collected during 1980 through 1989, the number of results above the 2-sigma counting error, the maximum and minimum individual sample results ( + or -2 -sigma counting error) observed during this time period, and the mean of all sample results $(+$ or -2 standard error of the mean) obtained during these years.

Radionuclide concentrations throughout this time period were extremely low and below applicable water quality standards in all cases. Radionuclides consistently detected in river water during these years were ${ }^{3} \mathrm{H},{ }^{90} \mathrm{Sr},{ }^{129} \mathrm{I},{ }^{234} \mathrm{U},{ }^{238} \mathrm{U}$, natural uranium $\left(\mathrm{U}_{\mathrm{NAT}}\right)$, and total uranium $\left(\mathrm{U}_{\mathrm{TOT}}\right)$. In addition, ${ }^{233} \mathrm{U}$ and ${ }^{239,240} \mathrm{Pu}$, while not detected all of the time, were observed to be above the analytical detection limit in $50 \%$ or more of the samples analyzed during the 10 -year period. Tritium, ${ }^{90} \mathrm{Sr}$, and ${ }^{129} \mathrm{I}$ existed in worldwide fallout, as well as in effluents from Hanford facilities. Uranium and ${ }^{3} \mathrm{H}$ occur naturally in the environment in addition to being present in Hanford effluents.

As discussed earlier, Priest Rapids Dam and the Richland Pumphouse were the primary Columbia River monitoring locations. Comparisons between sampling results from the two locations determined whether or not there was a statistically significant (paired sample comparison, $t$-test of differences; (Snedecor and Cochran 1980) increase in contaminants at the Richland Pumphouse, indicating a contribution attributable to Hanford activities. Table 3 compares the concentrations of radionuclides that 
Table 1. SESP Columbia River Water Monitoring Locations, 1980 Through 1989

\begin{tabular}{||l|l|l|}
\hline \multicolumn{1}{|c|}{ Location } & \multicolumn{1}{|c|}{ Sample Type } & Time of Operation \\
\hline Priest Rapids Dam & Composite & $1981-1989$ \\
& Continuous & $1980-1989$ \\
100-B Area & Composite & $1980-1984$ \\
Hanford Townsite & Composite & 1982 \\
& Continuous & 1982 \\
300 Area & Composite & $1980-1989$ \\
& Continuous & $1980-1989$ \\
Richland & Composite & $1980-1989$ \\
Pumphouse & Continuous & $1987-1989$ \\
& Grabs (Transects) & 1987 and 1988 \\
\hline
\end{tabular}

Table 2. Annual Average Columbia River Discharges at Priest Rapids Dam, 1980 Through 1989

\begin{tabular}{|c|c|}
\hline Year & Average Discharges \\
\hline 1980 & $103,000 \mathrm{cfs}$ \\
\hline 1981 & $132,000 \mathrm{cfs}$ \\
\hline 1982 & $140,000 \mathrm{cfs}$ \\
\hline 1983 & $131,000 \mathrm{cfs}$ \\
\hline 1984 & $112,000 \mathrm{cfs}$ \\
\hline 1985 & $107,000 \mathrm{cfs}$ \\
\hline 1986 & $108,000 \mathrm{cfs}$ \\
\hline 1987 & $101,000 \mathrm{cfs}$ \\
\hline 1988 & $100,000 \mathrm{cfs}$ \\
\hline 1989 & $99,400 \mathrm{cfs}$ \\
\hline
\end{tabular}


Table 3. Comparison of Selected Radionuclides in Columbia River Water at Priest Rapids Dam, the Richland Pumphouse, and the 300 Area, 1980 Through 1989

\begin{tabular}{|c|c|c|c|c|}
\hline \multirow{2}{*}{$\begin{array}{c}\text { Composite } \\
\text { System }\end{array}$} & \multicolumn{2}{|c|}{ Average Concentration, $\mathrm{pCi} / \mathrm{L}$} & \multirow{2}{*}{$\begin{array}{l}\text { Significant } \\
\text { Difference }\end{array}$} & \multirow[b]{2}{*}{ P-Value } \\
\hline & Priest Rapids Dam & Richland Pumphouse & & \\
\hline & $0.43 \pm 0.05$ & $0.49 \pm 0.04$ & $\mathbf{N}$ & 0.067 \\
\hline Total Beta & $2.2 \pm 0.8$ & $2.1 \pm 0.3$ & $\mathbf{N}$ & 0.504 \\
\hline${ }^{3} \mathbf{H}$ & $110 \pm 10$ & $170 \pm 14$ & $\mathbf{Y}$ & $<0.0001$ \\
\hline${ }^{90} \mathrm{Sr}$ & $0.14 \pm 0.01$ & $0.16 \pm 0.02$ & $\mathbf{N}$ & 0.0517 \\
\hline $\mathrm{U}_{\mathrm{NAT}}$ & $0.34 \pm 0.03$ & $0.46 \pm 0.04$ & $\mathbf{Y}$ & 0.0001 \\
\hline${ }^{234} U$ & $0.24 \pm 0.02$ & $0.25 \pm 0.02$ & $\mathbf{Y}$ & 0.023 \\
\hline${ }^{238} U$ & $0.19 \pm 0.01$ & $0.21 \pm 0.02$ & $\mathbf{N}$ & 0.105 \\
\hline $\mathrm{U}_{\text {TOT }}$ & $0.44 \pm 0.03$ & $0.47 \pm 0.04$ & $\mathbf{Y}$ & 0.034 \\
\hline $\begin{array}{l}\text { Continuous } \\
\text { System }\end{array}$ & Priest Rapids Dam & 300 Area & & \\
\hline \multirow[t]{2}{*}{${ }^{60} \mathrm{Co}$} & $0.0013 \pm 0.0004$ & $0.0049 \pm 0.0010$ & $\mathbf{Y}$ & $<0.0001$ \\
\hline & $0.0034 \pm 0.0012$ & $0.0083 \pm 0.0016$ & $\mathbf{Y}$ & $<0.0001$ \\
\hline${ }^{129} \mathrm{I}$ & $0.000009 \pm 0.000002$ & $0.000079 \pm 0.000013$ & $\mathbf{Y}$ & $<0.0001$ \\
\hline \multirow[t]{2}{*}{${ }^{137} \mathrm{Cs}$} & $0.009 \pm 0.002$ & $0.011 \pm 0.005$ & $\mathbf{N}$ & 0.467 \\
\hline & $0.018 \pm 0.003$ & $0.018 \pm 0.003$ & $\mathbf{N}$ & 0.254 \\
\hline \multirow[t]{2}{*}{${ }^{239 / 40} \mathrm{Pu}$} & $0.00005 \pm 0.00002$ & $0.00009 \pm 0.00010$ & $\mathbf{N}$ & 0.360 \\
\hline & $0.00012 \pm 0.00005$ & $0.00010 \pm 0.00004$ & $\mathbf{N}$ & 0.401 \\
\hline
\end{tabular}

were consistently detected in Columbia River water samples or that were commonly thought to be associated with Hanford operations during 1980 through 1989. Tritium and uranium $\left(\mathrm{U}_{\mathrm{NAT}}, \mathrm{U}_{\mathrm{TOT}}\right.$, and ${ }^{234} \mathrm{U}$ ) were found to be significantly higher in composite water samples collected at the Richland Pumphouse than in those from Priest Rapids Dam (5\% significance level). Strontium-90, while not significant at the $5 \%$ level, shows a P-value of 0.0517 (less than 0.05 considered significant), indicating that it was nearly significantly different. Iodine- 129 and ${ }^{60} \mathrm{Co}$ were found to be significantly elevated in continuous filter/resin samples collected at the 300 Area when compared to those collected at Priest Rapids Dam. Cesium-137 measured using the filter/resin system, on the other hand, was determined to be similar at the two locations. 
Results of Columbia River monitoring activities are discussed and illustrated in the following sections. Data presented in figures within the report include error bars indicative of 2 standard error of the calculated mean. Discussions are presented by radionuclide. Where appropriate, data generated during special studies are discussed along with data resulting from the routine Columbia River monitoring program.

\section{Total Alpha and Total Beta}

Total alpha and total beta measurements are useful indicators of the amount of radioactivity present in Columbia River water. Results of total alpha and total beta analyses generally are received from the analytical laboratory before specific radiochemical results. As such, these analyses provide an early indication of changes in the levels of radioactivity present in river water. All annual average total alpha and total beta concentrations in Columbia River water at Priest Rapids Dam, the 300 Area, and the Richland Pumphouse during 1980 through 1989 were approximately 5\% or less of the applicable water quality standards of 15 and $50 \mathrm{pCi} / \mathrm{L}$, respectively.

Figure 3 illustrates the annual average total alpha concentrations measured at Priest Rapids Dam, the 300 Area, and the Richland Pumphouse during 1980 through 1989. These data are presented in tabular form in Table A.9. During this time period, 67\% (189 out of 284) of the sampling results were greater than the analytical detection limit. While alpha concentrations appeared to be relatively stable during the 1980s, the total alpha concentrations were higher at the two downstream locations than at Priest Rapids Dam. The 10-year average total alpha concentrations measured at Priest Rapids Dam, the 300 Area, and the Richland Pumphouse were $0.43+/-0.05 \mathrm{pCi} / \mathrm{L}, 0.58+/-0.07 \mathrm{pCi} / \mathrm{L}$, and $0.49+/-0.04 \mathrm{pCi} / \mathrm{L}$, respectively. The higher alpha concentrations observed at the 300 Area reflect the influence of elevated uranium concentrations present in the ground water beneath the 300 Area (see Uranium Section). Statistical analysis of the differences between alpha concentrations at Priest Rapids Dam and the Richland Pumphouse verified that the concentrations at these two locations were not signiflcantly different (see Table 3).

The annual average total beta concentrations at Priest Rapids Dam, the 300 Area, and the Richland Pumphouse during the years of interest are presented in Figure 4 (Table A.10). Of the 284 beta results, $108(38 \%)$ were greater than the 2-sigma counting error. As in the case of total alpha, total beta concentrations were relatively stable over the 10-year period of interest. The concentrations of beta emitters at the three locations were similar throughout the 1980s, as is evident by the overlapping uncertainty bars in Figure 4. Statistical analysis of the results from samples from Priest Rapids Dam and the Richland Pumphouse confirmed that there was no significant difference in beta concentrations in samples collected from these two locations.

\section{Gamma Emitters}

Gamma scan analysis provided the ability to monitor for several specific gamma-emitting radionuclides of interest, including; ${ }^{60} \mathrm{Co},{ }^{65} \mathrm{Zn},{ }^{95} \mathrm{ZrNb},{ }^{106} \mathrm{Ru},{ }^{125} \mathrm{Sb},{ }^{144} \mathrm{CePr},{ }^{152} \mathrm{Eu},{ }^{154} \mathrm{Eu}$, and ${ }^{155} \mathrm{Eu}$. 


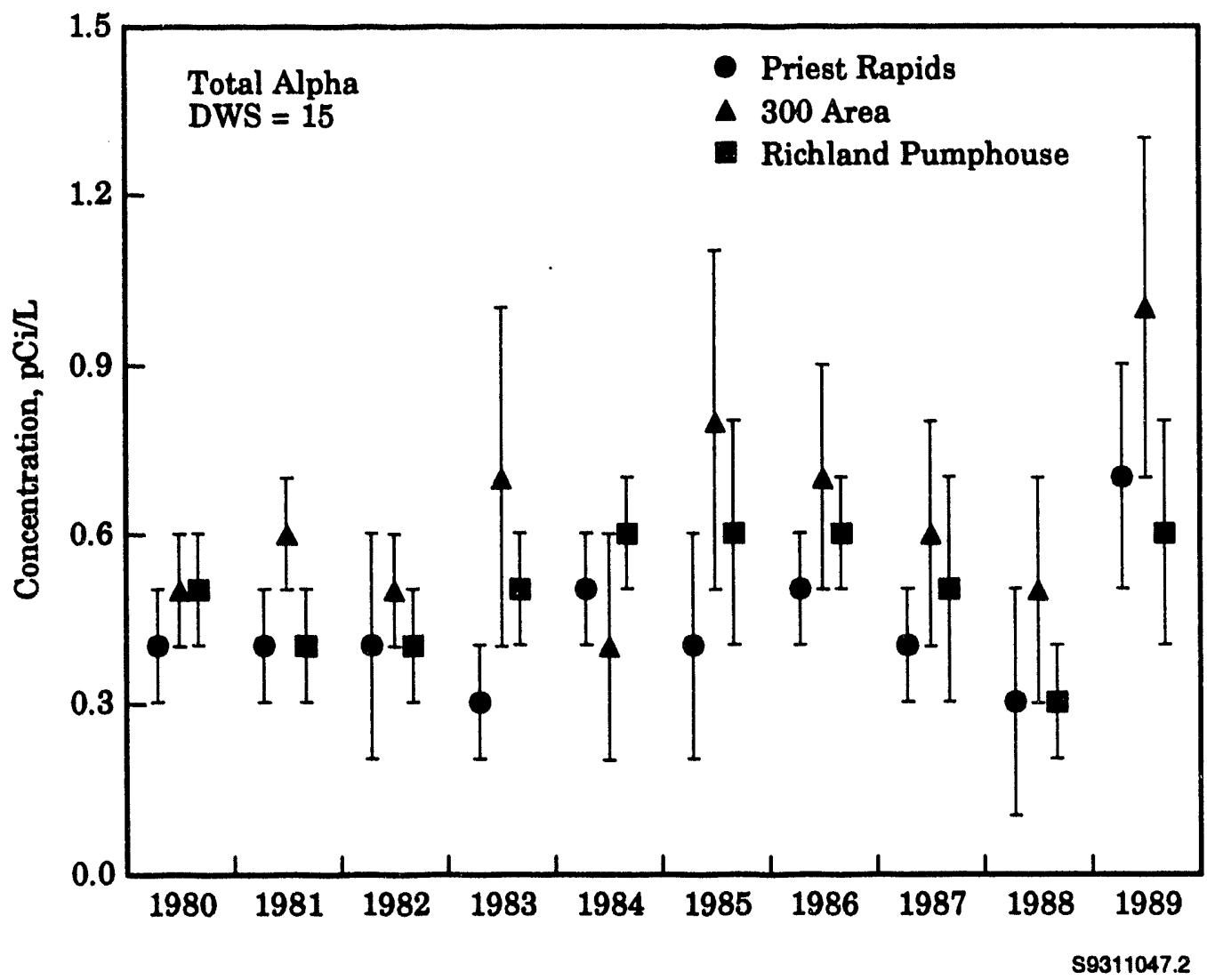

Figure 3. Annual Average Total Alpha Concentrations in Columbia River Water at Priest Rapids Dam, the 300 Area, and the Richland Pumphouse, 1980 Through 1989

In addition, other gamma-emitters present in measurable quantities were reported. Gamma scans were performed on bulk water samples collected using the composite sampling systems described earlier and on the filters and resin material collected using the continuous large-volume filter/resin sampling system also described previously.

No gamma-emitting radionuclides were consistently identified in bulk water samples collected using the composite sampling systems. Analytical detection levels were much lower on the filter/resin samples as a result of the much larger sample volumes. With the increase in sensitivity, only ${ }^{137} \mathrm{Cs}$ (approximately $60 \%$ ) and to a lesser extent ${ }^{60} \mathrm{Co}$ (approximately $30 \%$ ), were measured with some degree of regularity in the filter/resin samples. All gamma-emitters detected during the 10-year period of interest were well below applicable water quality standards.

Cesium-137 was detected in approximately $60 \%$ of the filter/resin samples collected during the years 1980 through 1989. The percentage of positive measurements was similar at Priest Rapids Dam, upstream of the Site, and in samples collected at the 300 Area and the Richland Pumphouse, both downstream of the Site. Statistical analysis of the differences between samples collected upstream and 


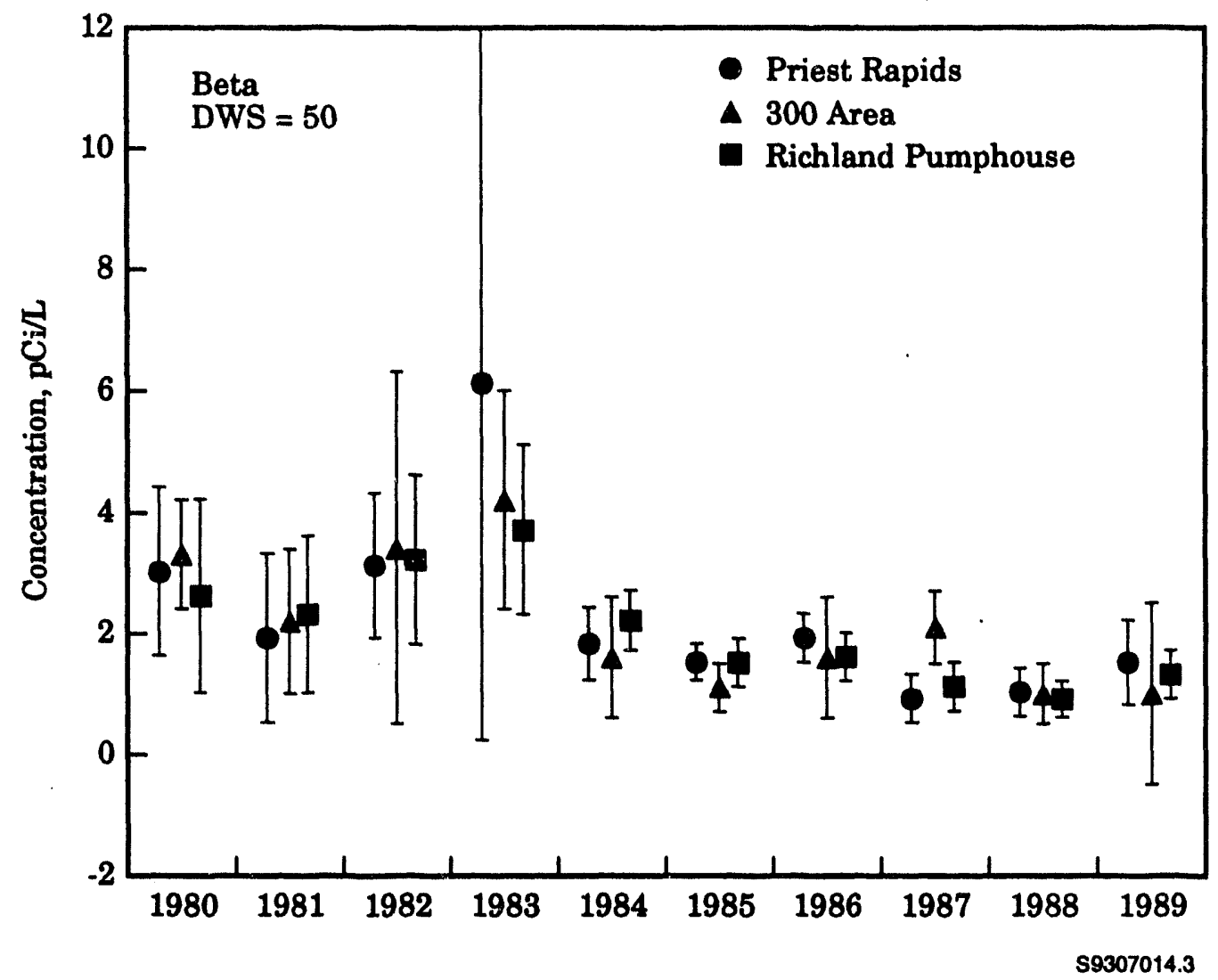

Figure 4. Annual Average Total Beta Concentrations in Columbia River Water at Priest Rapids Dam, the 300 Area, and the Richland Pumphouse, 1980 Through 1989

downstream of the Site revealed no significant differences (Table 3). All reported ${ }^{137} \mathrm{Cs}$ concentrations during the 1980 s were less than $5 \%$ of the applicable standard of $200 \mathrm{pCi} / \mathrm{L}$.

As previously noted, ${ }^{\circ} \mathrm{Co}$ was only detected in about $30 \%$ of the filter/resin samples collected during the 1980s. However ${ }^{60} \mathrm{Co}$ was detected more frequently in samples collected at the 300 Area and the Richland Pumphouse (approximately 40\%) than at Priest Rapids Dam (about 10\%), indicating a potential influence due to Hanford. Statistical analysis of the differences between the concentrations observed at Priest Rapids Dam and the 300 Area/Richland Pumphouse verified the difference to be significant. All ${ }^{60} \mathrm{Co}$ measurements were less than $10 \%$ of the water quality standard of $100 \mathrm{pCi} / \mathrm{L}$ during the years 1980 through 1989.

\section{Tritium}

During the 1980s, ${ }^{3} \mathrm{H}$ entered the Columbia River along the Hanford Reach through direct discharges and the seepage of contaminated ground water (Dirkes 1990; McCormack and Carlile 1984; Rokkan 1988). Special studies conducted during the 1980 s confirmed the discharge of contaminated 
ground water into the river at each of the 100 Areas, the 300 Area, and from the old Hanford Townsite to the 300 Area from the 200 Area ground-water plume (Dirkes 1990; McCormack and Carlile 1984).

The analytical technique used to determine ${ }^{3} \mathrm{H}$ concentrations in river water changed during the latter part of 1980 to lower the detection limit and measure the low concentrations of ${ }^{3} \mathrm{H}$ present in the water. Contractually, the detection limit was reduced from $300 \mathrm{pCi} / \mathrm{L}$ to $50 \mathrm{pCi} / \mathrm{L}$. The uncertainties associated with the results are indicative of this change. Note that the uncertainties associated with the 300 Area sampling results are greater than those associated with sampling results from the other two locations. This is due to the fact that the less sensitive, and less expensive, analytical technique was used at this location.

Annual average concentrations of ${ }^{3} \mathrm{H}$ in Columbia River water at Priest Rapids Dam, the 300 Area, and the Richland Pumphouse during 1980 through 1989 are shown in Figure 5 (Table A.11). Tritium concentrations sxceeded the detection limit in 97\% (277 out of 287) of the samples analyzed. All of the less-than-detectable results were at the 300 Area, indicative of a less sensitive analytical technique. All ${ }^{3} \mathrm{H}$ results during the 1980 s were well below the applicable water quality standard of $20,000 \mathrm{pCi} / \mathrm{L}$, typically $5 \%$ or less than the standard. Tritium concentrations were consistently higher at the 300 Area

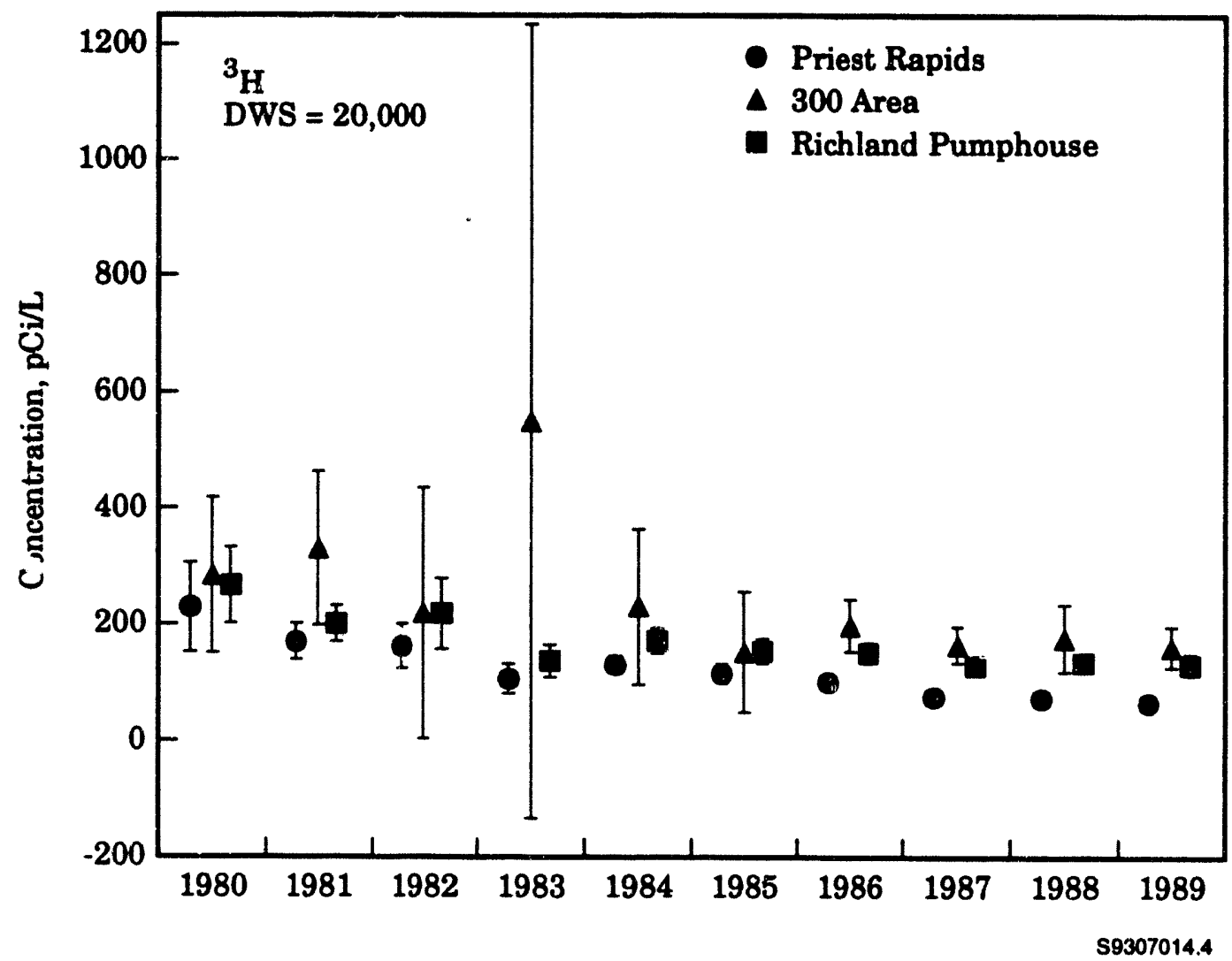

Figure 5. Annual Average Tritium $\left({ }^{3} \mathrm{H}\right)$ Concentrations in Columbia River Water at Priest Rapids Dam, the 300 Area, and the Richland Pumphouse, 1980 Through 1989 
and the Richland Pumphouse than at Priest Rapids Dam throughout the 1980s. Statistical analysis of the ${ }^{3} \mathrm{H}$ concentrations at Priest Rapids Dam and the Richland Pumphouse confirmed that they were significantly different, indicating an influence from Hanford.

Routine Columbia River monitoring data during recent years have shown a general decrease in ${ }^{3} \mathrm{H}$ concentrations in Columbia River water. This observed decline is more rapid than would be expected solely as a result of radioactive decay (12-year half-life). Studies conducted following the U.S. Pacific nuclear weapons tests indicated that the effective residence time of ${ }^{3} \mathrm{H}$ deposited on the North American continent is approximately 5.7 years (NCRP 1979).

The downward trend in ${ }^{3} \mathrm{H}$ levels, evident at the Priest Rapids Dam, 300 Area, and Richland Pumphouse locations, was not consistent. The differences between ${ }^{3} \mathrm{H}$ concentrations observed at the Richland Pumphouse and Priest Rapids Dam have varied, increasing slightly during the late 1980s (Figure 6). This difference could have resulted from lower river flows during the late 1980s (i.e., less dilution), a nonuniform distribution of ${ }^{3} \mathrm{H}$ across the river as a result of the location of ground-water discharges relative to the san pling location, or a combination thereof. A special study conducted during the summers of 1987 and 1988 concluded that, under most flow conditions, a ${ }^{3} \mathrm{H}$ concentration gradient existed across the Columbia River at the Richland Pumphouse (Dirkes 1993).

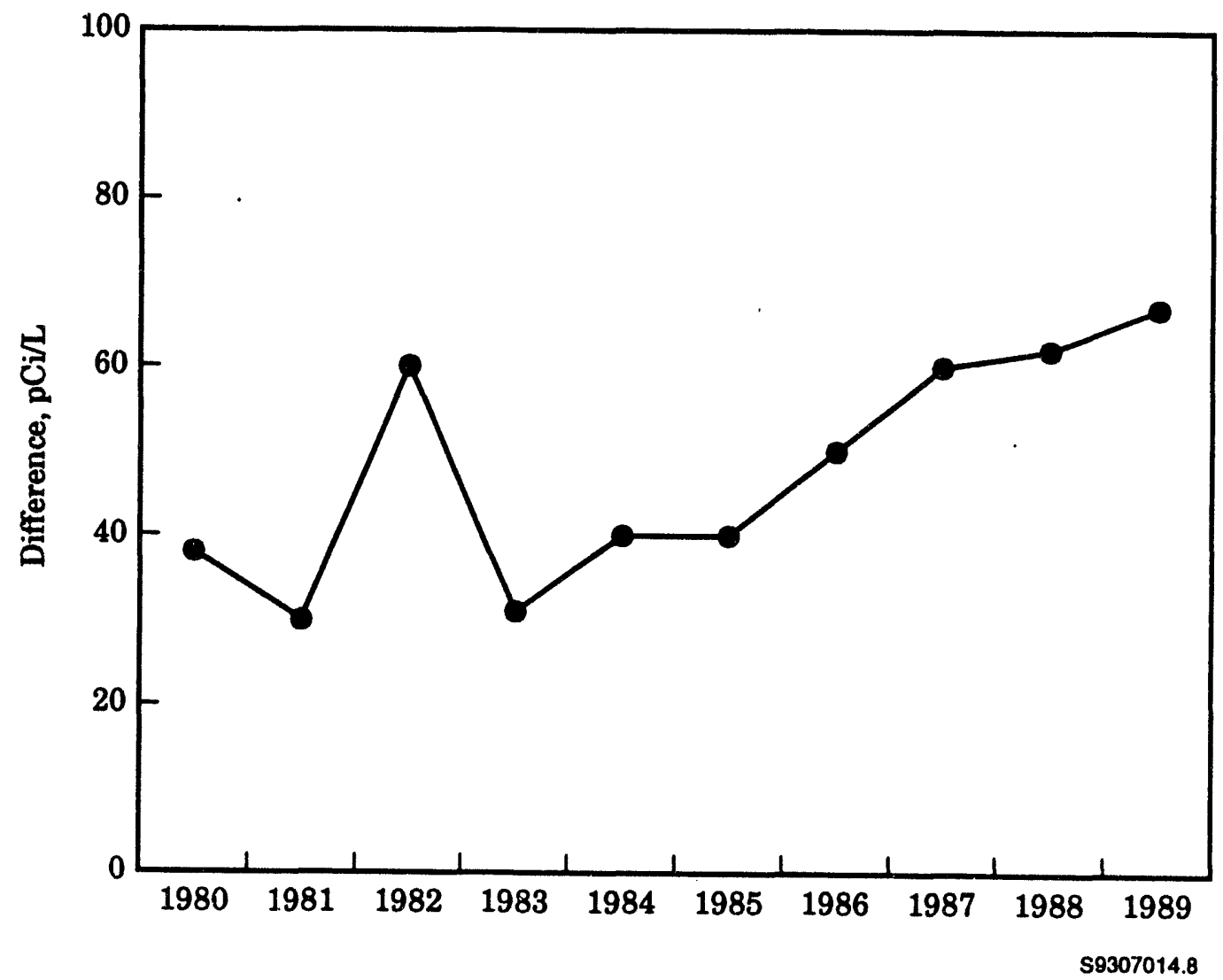

Figure 6. Difference in Annual Average Tritium $\left({ }^{3} \mathrm{H}\right)$ Concentrations in Columbia River Water from Priest Rapids Dam and the Richland Pumphouse, 1980 Through 1989 


\section{Strontium}

The primary source of ${ }^{90} \mathrm{Sr}$ entering the Columbia River and attributable to Hanford operations has been the 100-N Area liquid waste disposal facilities, which are known to discharge to the river via ground-water seepage. Routine effluent monitoring and special studies documented the presence of elevated levels of ${ }^{90} \mathrm{Sr}$ in the N Springs flowing into the Columbia River (Dirkes 1990; McCormack and Carlile 1984; Rokkan 1988).

Annual average concentrations of ${ }^{90} \mathrm{Sr}$ in Columbia River water at Priest Rapids Dam, the 300 Area, and the Richland Pumphouse during 1980 through 1989 are shown in Figure 7 (Table A.12) and indicate a slight decline during the latter part of the decade. The concentrations of ${ }^{90} \mathrm{Sr}$ in river water exceeded the detection limit in 247 out of 253 water samples (98\%) submitted during the 1980s. All ${ }^{90} \mathrm{Sr}$ results during these years were well below the applicable water quality standard of $8 \mathrm{pCi} / \mathrm{L}$, typically less than $12 \%$ of the standard. Strontium- 90 concentrations were generally similar at Priest Rapids Dam, the 300 Area, and the Richland Pumphouse throughout the 1980s. Statistical analysis of the ${ }^{90} \mathrm{Sr}$ concentrations at Priest Rapids Dam and the Richland Pumphouse confirmed that they were not

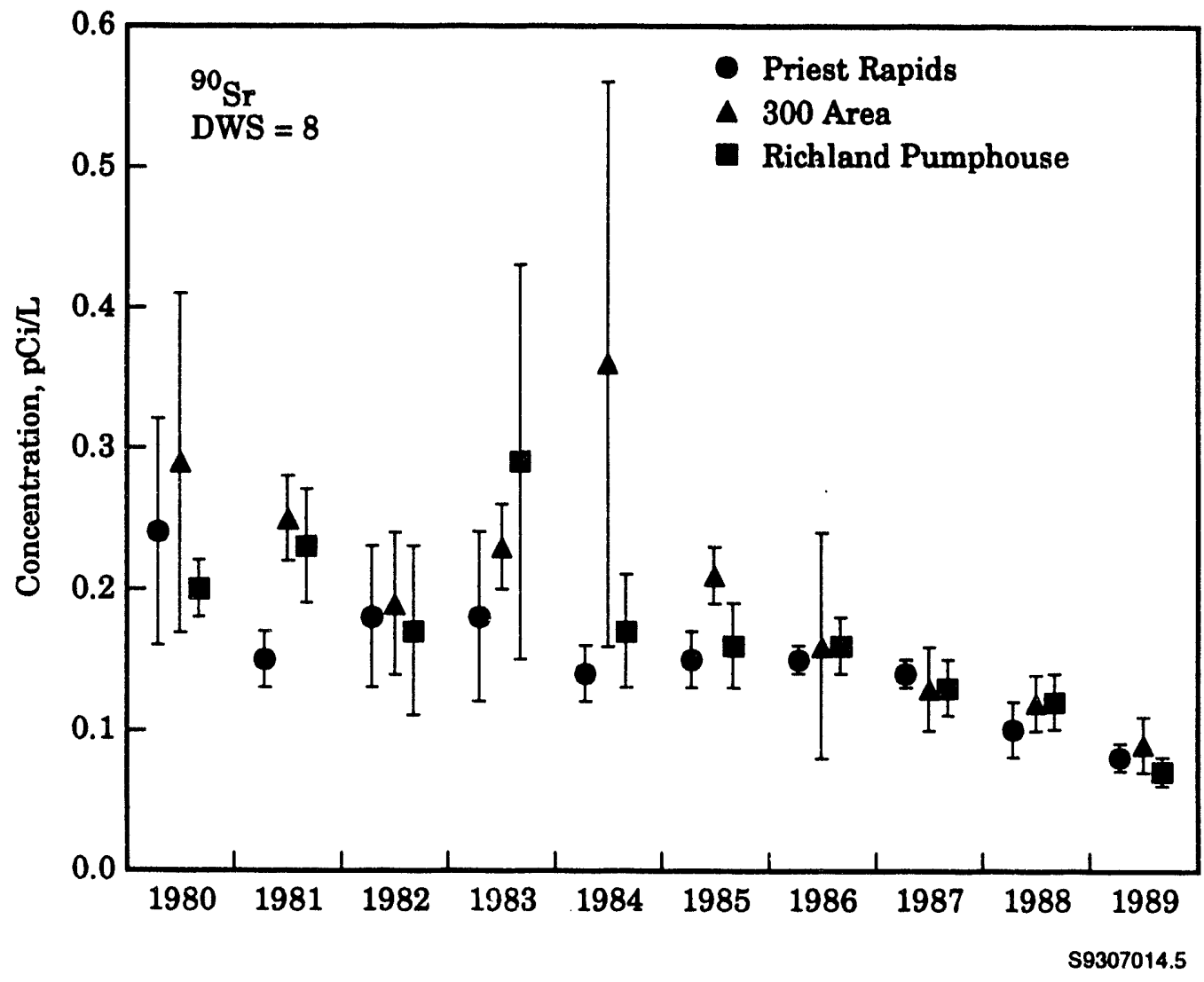

Figure 7. Annual Average Strontium-90 ( $\left.{ }^{90} \mathrm{Sr}\right)$ Concentrations in Columbia River Water at Priest Rapids Dam, the 300 Area, and the Richland Pumphouse, 1980 Through 1989 
significantly different (P-value greater than 0.005$)$; however, the P-value given in Table $3(0.0517)$ indicates they very nearly were different (at the $5 \%$ significance level) and likely indicative of an influence attributable to Hanford operations.

\section{Uranium}

Uranium was present at elevated concentrations, relative to river water concentrations, in the ground water beneath the 300 Area and was documented to be entering the river through riverbank springs along the shoreline (Dirkes 1990; Jaquish and Bryce 1989; McCormack and Carlile 1984). Seepage of contaminated ground water was reported just upstream of the 300 Area Columbia River sampling location along the Hanford shoreline. Elevated uranium concentrations from natural uranium deposits, at levels similar to those in the 300 Area ground water, were also reported in irrigation water returns and seepage across the river from the Hanford Site (Dirkes 1990).

The analytical technique used to measure uranium in river water changed during the mid-1980s. During the years 1980 through 1985, uranium concentrations in river water were measured as total uranium (termed $\mathrm{U}_{\mathrm{NAT}}$ ). In 1986, isotopic uranium analysis was initiated. This modification provided the concentrations of the individual uranium isotopes, ${ }^{234} \mathrm{U},{ }^{235} \mathrm{U}$, and ${ }^{238} \mathrm{U}$. In addition, the total uranium (labelled $U_{\text {TOT }}$ ) concentrations, useful for comparison to previous years, could be determined by summing the individual isotopic concentrations.

Annual average uranium concentrations during the 1980s are plotted in Figure 8, indicating the levels in the river water to be relatively stable with time. Uranium, $U_{\text {NAT }}$ and $U_{\text {TOT, }}$, was consistently detected throughout the 1980 s $(99 \%, 267$ out of 270$)$. While there was not a drinking water standard for uranium during the 1980s, the concentrations of uranium measured in Columbia River water during this decade were much less than a recently proposed standard of $30 \mathrm{pCi} / \mathrm{L}$. Average uranium concentrations in Columbia River water were slightly higher at the 300 Area and Richland Pumphouse than at Priest Rapids Dam during 1980 through 1989. Statistical analysis of the differences between uranium concentrations at Priest Rapids Dam and the Richland Pumphouse revealed the difference to be significant (5\% significance level). Annual average uranium concentrations measured at the 300 Area were also consistently slightly greater than those at the Richland Pumphouse, as evident in Figure 8 (Table A.13). This difference reflects the proximity of the 300 Area sampling location with respect to the seepage of ground water containing elevated levels of uranium, which would not be uniformly dispersed across the river.

\section{Radioiodine}

lodine-129, similar to ${ }^{3} \mathrm{H}$ is associated with the contaminated 200 Area ground-water plume that entered the Columbia River along the Hanford Reach during the 1980s (Dirkes 1990; McCormack and Carlile 1984). Special studies conducted during these years confirmed the discharge of ground water containing elevated concentrations of ${ }^{129} 1$ into the river near the old Hanford Townsite (Dirkes 1990; McCormack and Carlile 1984). 


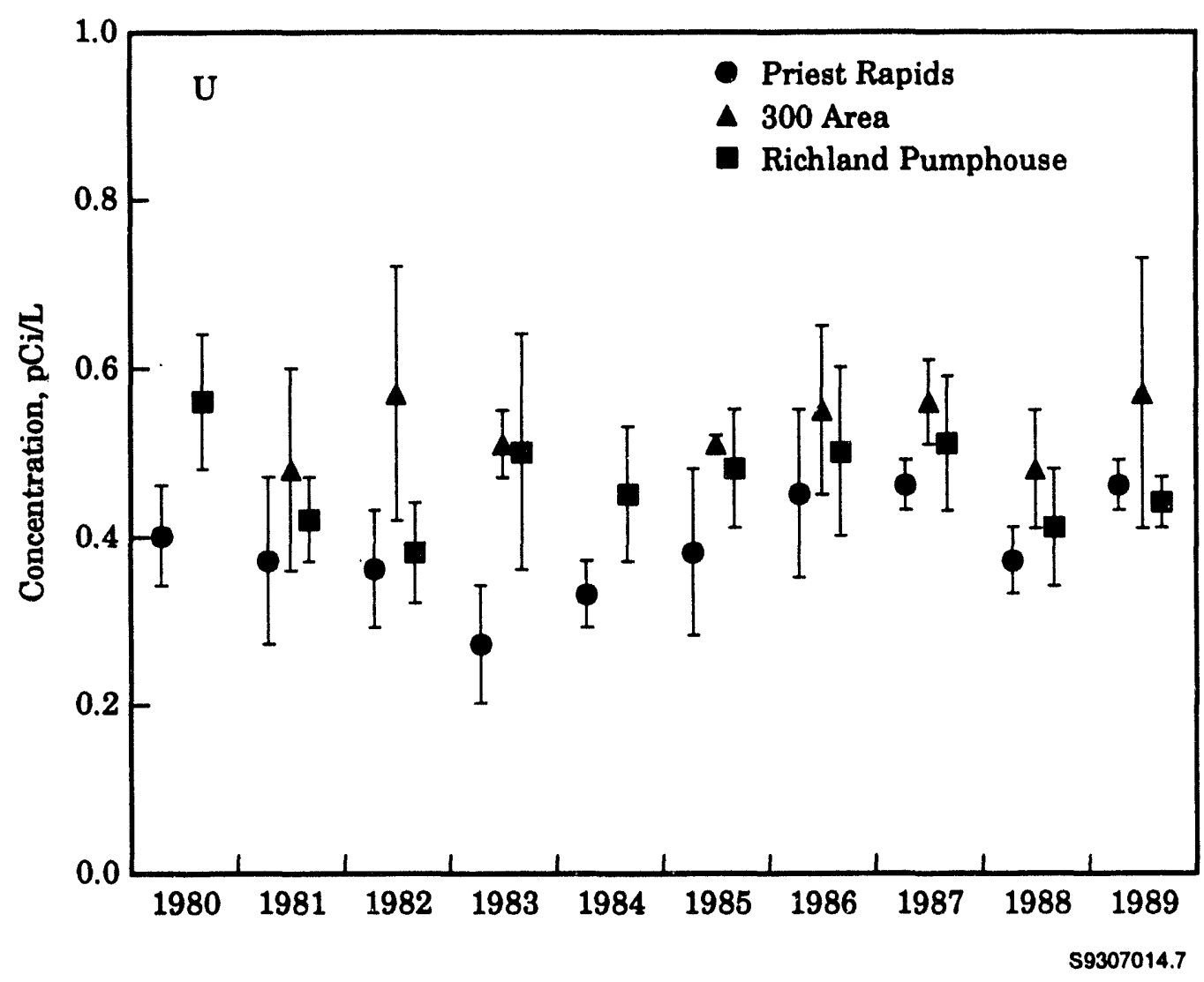

Figure 8. Annual Average Uranium Concentrations in Columbia River Water at Priest Rapids Dam, the 300 Areq, and the Richland Pumphouse, 1980 Through 1989

Annual average concentrations of ${ }^{129} \mathrm{~T}$ in Columbia River water at Priest Rapids Dam, the 300 Area, and the Richland Pumphouse during 1980 through 1989 are shown in Figure 9 (Table A.14). Special sampling and analytical techniques were used to detect the extremely low levels of ${ }^{129} \mathrm{I}$ present in the river water. Using these techniques, ${ }^{129} \mathrm{I}$ was detected in $98 \%$ (126 out of 128) of the samples analyzed. All ${ }^{129} \mathrm{~T}$ results reported during the 1980 s were much less than the applicable water quality standard of $1 \mathrm{pCi} / \mathrm{L}$, typically less than one-tenth of $1 \%$ of the standard. Iodine-129 concentrations were consistently higher at the 300 Area and the Richland Pumphouse (where ${ }^{129}$ I sampling was initiated in 1987) than at Priest Rapids Dam. Statistical analysis of the ${ }^{129} \mathrm{I}$ concentrations at Priest Rapids Dam and the 300 Area confirmed that they were significantly different $(P=<0.0001)$, indicating an influence from Hanford activities. Similar statistical comparisons of data obtained from the 300 Area and Richland Pumphouse indicated that there was no significant difference.

A slight increase in the concentrations of ${ }^{129} \mathrm{I}$ at the 300 Area during the $1980 \mathrm{~s}$ is apparent in Figure 9. Annual average river discharges during the same time period have been decreasing (see Table 2), which may account in part for the observed increases in ${ }^{129} \mathrm{I}$ concentrations because of less dilution of the contaminants. However, the proximity of the 200 Area ground-water plume (which was nearing the 300 Area) to the sampling location most likely accounts for this increasing trend. As was 


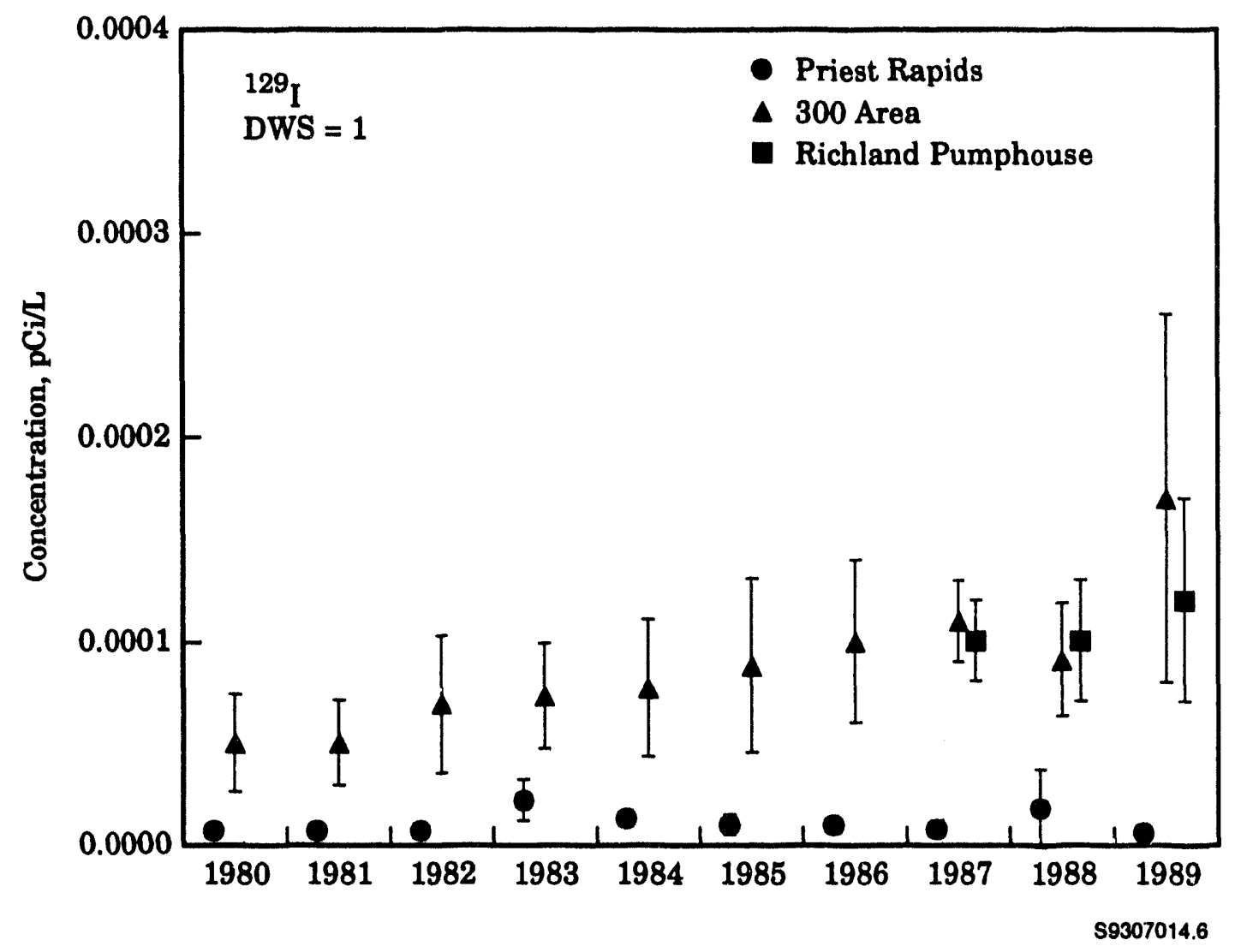

Figure 9. Annual Average lodine-129 $\left({ }^{129} \mathrm{I}\right)$ Concentrations in Columbia River Water at Priest Rapids Dam, the 300 Area, and the Richland Pumphouse, 1980 Through 1989

shown with ${ }^{3} \mathrm{H}$ during a special study conducted during the late 1980 s, ${ }^{129} \mathrm{I}$ is not expected to be completely mixed across the river at the Richland Pumphouse sampling location (Dirkes 1993). The nearer the plume gets to the sampling location, the more exaggerated the gradient becomes, resulting in higher concentrations of ${ }^{129} 1$ along the Hanford shoreline.

\section{Plutonium}

Plutonium was analyzed on the filters and resins collected using the continuous sampling system. Sample results were available for both the particulate and soluble fractions. The concentration of ${ }^{239,240} \mathrm{Pu}$ in river water exceeded the detection limit in 138 out of 192 analyses $(72 \%)$ performed during the 1980s. Of the 96 filters, $87(91 \%)$ displayed positive ${ }^{239,240} \mathrm{Pu}$ results, while only 51 of $96(53 \%)$ resins were found to contain measurable amounts. Plutonium-239,240 concentrations were generally similar at Priest Rapids Dam, the 300 Area, and Richland Pumphouse throughout the 1980s. Statistical analysis of the concentrations at Priest Rapids Dam and the 300 Area confirmed that they were not significantly different $(P=0.366$ on filter samples; $P=0.401$ on the resins). 


\section{References}

40 CFR 141. U.S. Environmental Protection Agency, "National Primary Drinking Water Regulations." Code of Federal Requlations.

Andersen, B. V. 1959. Hanford Environmental Monitoring Annual Report 1958. HW-61676, General Electric Company, Hanford Atomic Products Operation, Richland, Washington.

Backman, G. E. 1962. Dispersion of 300 Area Liquid Effluent in the Columbia River. HW-73672, General Electric Company, Hanford Atomic Products Operation, Richland, Washington.

Becker, C. D. 1990 . Aquatic Bioenvironmental Studies: The Hanford Experience, 1944-84. Elsevier Science Publishing Company, Inc., New York.

Becker, C. D., and R. H. Gray. 1992. "Past and Present Water-Quality Conditions in the Hanford Reach, Columbia River." Environmental Monitoring and Assessment. 22:137-152, Kluwer Academic Publishers, The Netherlands.

Becker, C. D. and D. A. Neitzel. 1992. Water Ouality in North Americal River Systems. Battelle Press, Columbus, Ohio.

Bramson, P. E., and J. P. Corley. 1972. Environmental Surveillance at Hanford for CY 1971. BNWL-1669, Pacific Northwest Laboratory, Richland, Washington.

Corley, J. P. 1970. Evaluation of Radiological Conditions in the Vicinity of Hanford for 1969. BNWL-1505, Pacific Northwest Laboratory, Richland, Washington.

Corley, J. P. 1973. Environmental Surveillance at Hanford for CY-1970. BNWL-1669, Pacific Northwest Laboratory, Richland, Washington.

Corley, J. P. and C. B. Wooldridge. 1969. Evaluation of Radiological Conditions in the Vicinity of Hanford for 1967. BNWL-983, Pacific Northwest Laboratory, Richland, Washington.

Corley, J. P., D. H. Denham, R. E. Jaquish, D. E. Michels, A. R. Olsen, and D. A. Waite. 1981. A Guide For: Environmental Radiological Surveillance At U.S. Department of Energy Installations. DOE/EP-0023, U.S. Department of Energy, Washington, D.C.

Cushing, C. E. 1988. Hanford Site National Environmental Policy Act (NEPA) Characterization. PNL-6415, Rev. 1, Pacific Northwest Laboratory, Richland, Washington.

Cushing, C. E., D. G. Watson, A. J. Scott, and J. M. Gurtisen. 1981. "Decrease of Radionuclides in Columbia River Biota Following Closure of Hanford Reactors." Health Physics 41:59-67. 
Dauble, D. D., and D. G. Watson. 1990. Spawning and Abundance of Fall Chinook Salmon (Oncorhynchus tshawytscha) in the Hanford Reach of the Columbia River. 1948-1988. PNL-7289, Pacific Northwest Laboratory, Richland, Washington.

Dirkes, R. L. 1990. 1990 Hanford Riverbank Springs Characterization Report. PNL-7500, Pacific Northwest Laboratory, Richland, Washington.

Dirkes, R. L. 1992. Columbia River Monitoring Data Compilation. WHC-SD-EN-DP-024, Westinghouse Hanford Company, Richland, Washington.

Dirkes, R. L. 1993. Columbia River Monitoring: Distribution of Tritium in Columbia River Water at the Richland Pumphouse. PNL-8531, Pacific Northwest Laboratory, Richland, Washington.

Dirkes, R. L., G. W. Patton, and B. L. Tiller. 1993. Columbia River Monitoring: Summary of Chemical Monitoring Alone Cross Sections at Vernita Bridge and Richland. PNL-8531, Pacific Northwest Laboratory, Richland, Washington.

DOE (U.S. Department of Energy). 1991. Environmental Regulatory Guide for Radiological Effluent Monitoring and Environmental Surveillance. DOE/EH-0173T, U.S. Department of Energy, Washington, D. C.

DOE-RL (U.S. Department of Energy, Richland Field Office). 1991. Environmental Monitoring Plan United States Department of Energy Richland Field Office. DOE/RL 91-50, U.S. Department of Energy, Richland, Washington.

DOE-RL (U.S. Department of Energy, Richland Field Office). 1992. Sampling and Analysis of 100 Area Springs. DOE/RL-92-12 Rev 1, U.S. Department of Energy, Richland, Washington.

ERDA (U.S. Energy, Research and Development Administration). 1975. Final Environmental Statement. Waste Management Operations, Hanford Reservation, Richland. Washington. ERDA-1538, U.S. Energy Research and Development Administration, Richland, Washington.

Evans, J. C., R. W. Bryce, and D. J. Bates. 1992. Hanford Site Ground-Water Monitoring for 1991. PNL-8284, Pacific Northwest Laboratory, Richland, Washington.

Fisher, W. L., and C. B. Wilson. 1970. Evaluation of Radiological Conditions in the Vicinity of Hanford for 1968. BNWL-1341, Pacific Northwest Laboratory, Richland, Washington.

Fix, J. J., and D. E. Robertson. 1976. "A 'Filter-Resin' Sampling Method for Measurement of Radioactivity in Columbia River Water." BNWL-SA-5630, Pacific Northwest Laboratory, Richland, Washington.

Foster, R. F., and R. H. Wilson. 1964. Evaluation of Radiological Conditions in the Vicinity of Hanford for 1963. HW-80991, U.S. Atomic Energy Commission, Washington, D.C.

Foster, R. F., and R. H. Wilson. 1965. Evaluation of Radiological Conditions in the Vicinity of Hanford for 1964. BNWL-90, Pacific Northwest Laboratory, Richland, Washington. 
Foster, R. F., and R. H. Wilson. 1965. Evaluation of Radiological Conditions in the Vicinity of Hanford for 1964. BNWL-90, Pacific Northwest Laboratory, Richland, Washington.

Foster, R. F. 1966. Evaluation of Radiological Conditions in the Vicinity of Hanford for 1965. BNWL-316, Pacific Northwest Laboratory, Richland, Washington.

Freshley, M. D., and M. J. Graham. 1988. Estimation of Ground-Water Travel Time at the Hanford Site: Description. Past Work, and Future Needs. PNL-6328, Pacific Northwest Laboratory, Richland, Washington.

Haney, W. A. 1957. Dilution of 300 Area Uranium Wastes Entering the Columbia River. HW52401, General Electric Company, Hanford Atomic Products Operation, Richland, Washington.

Hanf, R. W., and R. L. Dirkes. 1992. Surface Environmental Surveillance Procedures Manual. PNL-MA-580, Rev 1, Pacific Northwest Laboratory, Richland, Washington.

Honstead, J. F. 1954. Columbia River Survey 1951. 1952. 1953. HW-32506, General Electric Company, Hanford Atomic Products Operation, Richland, Washington.

Honstead, J. F. 1957. Dispersion of Dissolved Material in the Columbia River. HW-49008, General Electric Company, Hanford Atomic Products Operation, Richland, Washington

Honstead, J. F. 1967. Evaluarion of Radiological Conditions in the Vicinity of Hanford for 1966. BNWL-439, Pacific Northwest Laboratory, Richland, Washington.

Honstead, J. F., J. W. Healy, and H. J. Paas. 1951. Columbia River Survey Preliminary Report. HW-22851, AEC Research and Development Report, Hanford Atomic Products Operation, Richland, Washington.

Jaquish, R. J., and R. W. Bryce. 1989. Hanford Site Environmental Report for Calendar Year 1988. PNL-6825, Pacific Northwest Laboratory, Richland, Washington.

Jaquish, R. J., and R. W. Bryce. 1990. Hanford Site Environmental Report for Calendar Year 1989. PNL-7346, Pacific Northwest Laboratory, Richland, Washington.

Jaquish, R. J., and P. J. Mitchell. 1988. Hanford Site Environmental Report for Calendar Year 1987. PNL-6464, Pacific Northwest Laboratory, Richland, Washington.

Maas, L. J. 1981. Hanford Sanitary Water Ouality Surveillance CY-1980. HEHF-33, Hanford Environmental Health Foundation, Richland, Washington.

Maas, L. J. 1982. Hanford Sanitary Water Ouality Surveillance CY-1981. HEHF-36, Hanford Environmental Health Foundation, Richland, Washington.

Maas, L. J. 1983. Hanford Sanitary Water Ouality Surveillance CY-1982. HEHF-39, Hanford Environmental Health Foundation, Richland, Washington. 
Maas, L. J. 1984. Hanford Sanitary Water Quality Surveillance CY-1983. HEHF-42, Hanford Environmental Health Foundation, Richland, Washington.

Maas, L. J. 1985. Hanford Sanitary Water Quality Surveillance CY-1984. HEHF-45, Hanford Environmental Health Foundation, Richland, Washington.

Manley, C. L. 1992. Environmental Releases for Calendar Year 1991. WHC-EP-0527-1, Westinghouse Hanford Company, Richland, Washington.

McCormack, W. D., and J.M.V. Carlile. 1984. Investigation of Ground-Water Seepage from the Hanford Shoreline of the Columbia River. PNL-5289, Pacific Northwest Laboratory, Richland, Washington.

McGavock, E. H., W. D. Wiggens, R. L. Blazs, P. R. Boucher, L. L. Reed, and M. C. Smith. 1987. Water Resources Data Washington Water Year 1985. U.S. Geological Survey, Tacoma, Washington.

NCRP (National Council on Radiation Protection and Measurements). 1979. Tritium in the Environment. Report No. 62, NCRP, Bethesda, Maryland.

Norton, H. T. 1957. The Turbulent Diffusion of River Contaminants. HW-49195, General Electric Company, Hanford Atomic Products Operation, Richland, Washington.

Peterson, R. E., and V. G. Johnson. 1992. Riverbank Seepage of Groundwater Along the 100 Areas Shoreline. Hanford Site. WHC-EP-0609, Westinghouse Hanford Company, Richland, Washington.

PNL (Pacific Northwest Laboratory). 1987. Environmental Monitoring at Hanford for 1986. PNL6120, Pacific Northwest Laboratory, Richland, Washington.

Price, K. R. 1986. Environmental Monitoring at Hanford for CY-1985. PNL-5817, Pacific Northwest Laboratory, Richland, Washington.

Price, K. R., J.M.V. Carlile, R. L. Dirkes, and M. S. Trevathan. 1984. Environmental Surveillance at Hanford for CY-1983. PNL-5038, Pacific Northwest Laboratory, Richland, Washington.

Price, K. R., J.M.V. Carlile, R. L. Dirkes, R. E. Jaquish, M. S. Trevathan, and R. K. Woodruff. 1985. Environmental Monitoring at Hanford for CY-1984. PNL-5407, Pacific Northwest Laboratory, Richland, Washington.

Rokkan, D. J. 1988. Westinghouse Hanford Company 100 Areas Environmental Releases for 1987. WHC-EP-0165, Westinghouse Hanford Company, Richland, Washington.

Snedecor, G. W., and W. G. Cochran. 1980. Statistical Methods. 7th ed. Iowa State University Press, Ames, lowa.

Soldat, J. K. 1962. A Compilation of Basic Data Relating to the Columbia River Section 8 Dispersion of Reactor Effluent in the Columbia River. HW-69369, General Electric Company, Hanford Atomic Products Operation, Richland, Washington. 
Somers, S. R. 1987. Hanford Sanitary Warer Ouality Surveillance CY-1986. HEHF-59, Hanford Environmental Health Foundation, Richland, Washington.

Somers, S. R. 1988. Hanford Sanitary Water Ouality Surveillance CY-1987. HEHF-71, Hanford Environmental Health Foundation, Richland, Washington.

Somers, S. R. 1989. Hanford Sanitary Water Ouality Surveillance CY-1988. HEHF-74, Hanford Environmental Health Foundation, Richland, Washington.

Sonnichsen, J. C., Jr., D. A. Kottwitz, and R. T. Jaske. 1970. Dispersion Characteristics of the Columbia River Between River Miles 383 and 355. BNWL-1477, Paciflc Northwest Laboratory, Richland, Washington.

Sula, M. J., and P. J. Blumer. 1981. Environmental Surveillance at Hanford for CY-1980. PNL-3728, Pacific Northwest Laboratory, Richland, Washington.

Sula, M. J., W. D. McCormack, R. L. Dirkes, K. R. Price, and P. A. Eddy. 1982. Environmental Surveillance at Hanford for CY-1981. PNL-4211, Pacific Northwest Laboratory, Richland, Washington.

Sula, M. J., J.M.V. Carlile, K. R. Price, and W. D. McCormack. 1983. Environmental Surveillance at Hanford for CY-1982. PNL-4657, Pacific Northwest Laboratory, Richland, Washington.

Thurman, P. A. 1990. Hanford Sanitary Water Ouality Surveillance CY-1989. HEHF-76, Hanford Environmental Health Foundation, Richland, Washington.

Walters, W. H., R. L. Dirkes, and B. A. Napier. 1992. Literature and Data Review for the SurfaceWater Pathway: Columbia River and Adjacent Coastal Areas. PNWD-2034 HEDR, Battelle, Pacific Northwest Laboratories, Richland, Washington.

WDOE (Washington State Department of Ecology). 1982. Water Ouality Standards for Waters of the State of Washington. Washington Administrative Code, Chapter 173-201, Olympia, Washington.

WDOE (Washington State Department of Ecology). 1992. Water Ouality Standards for Waters of the State of Washington. Washington Administrative Code, Chapter 173-201a, Olympia, Washington.

Woodruff, R. K., R. W. Hanf, and R. E. Lundgren. 1992. Hanford Site Environmental Report for Calendar Year 1991. PNL-8148, Pacific Northwest Laboratory, Richland, Washington.

Woodruff, R. K., R. W. Hanf, and R. E. Lundgren. 1993. Hanford Site Environmental Report for Calendar Year 1992. PNL-8682, Pacific Northwest Laboratory, Richland, Washington. 


\section{Appendix}

\section{Summaries of Columbia River Water Sampling Results}


Table A.1. Summary of Radionuclide Concentrations in Columbia River Water at Priest Rapids Dam, 1980 Through 1989; Composite Sampling System

\begin{tabular}{|c|c|c|c|c|c|}
\hline \multirow[b]{2}{*}{ Constituent } & \multirow{2}{*}{$\begin{array}{l}\text { Total \# } \\
\text { Samples }\end{array}$} & \multirow{2}{*}{$\begin{array}{l}\text { \# Results } \\
>2 \text { Sig CE }\end{array}$} & \multicolumn{3}{|c|}{ Concentration, $\mathrm{pCi} / \mathrm{L}$} \\
\hline & & & Maximum & Minimum & Average \\
\hline Total Alpha & 111 & 64 & $1.2 \pm 0.6$ & $-0.1 \pm 0.2$ & $0.4 \pm 0.1$ \\
\hline Total Beta & 111 & 43 & $40.9 \pm 6.1$ & $-1.7 \pm 4.9$ & $2.2 \pm 0.8$ \\
\hline Gamma Scan & & & & & \\
\hline${ }^{80} \mathrm{Co}$ & 111 & 21 & $1.8 \pm 1.1$ & $-1.8 \pm 1.2$ & $0.09 \pm 0.12$ \\
\hline${ }^{\omega} \mathrm{Zn}$ & 111 & 19 & $14.3 \pm 16.5$ & $-6.6 \pm 4.0$ & $0.22 \pm 0.37$ \\
\hline${ }^{106} \mathrm{Ru}$ & 111 & 7 & $7.1 \pm 5.0$ & $-13.6 \pm 15.1$ & $-0.64 \pm 0.83$ \\
\hline${ }^{137} \mathrm{Cs}$ & 111 & 9 & $1.5 \pm 0.8$ & $-1.5 \pm 1.8$ & $-0.06 \pm 0.09$ \\
\hline${ }^{14} \mathrm{CePr}$ & 111 & 5 & $12.8 \pm 7.8$ & $-41.2 \pm 164$ & $-0.89 \pm 1.46$ \\
\hline${ }^{3} \mathrm{H}$ & 116 & 116 & $325 \pm 18$ & $40 \pm 11$ & $111 \pm 10$ \\
\hline${ }^{9} \mathrm{Sr}$ & 104 & 23 & $0.3 \pm 0.1$ & $-0.3 \pm 0.3$ & $0.05 \pm 0.02$ \\
\hline${ }^{90} \mathrm{Sr}$ & 104 & 102 & $0.46 \pm 0.03$ & $0.02 \pm 0.03$ & $0.14 \pm 0.01$ \\
\hline${ }^{234} \mathrm{U}$ & 52 & 52 & $0.40 \pm 0.07$ & $0.03 \pm 0.01$ & $0.24 \pm 0.02$ \\
\hline${ }^{235} \mathrm{U}$ & 52 & 17 & $0.04 \pm 0.02$ & $-0.007 \pm 0.014$ & $0.009 \pm 0.002$ \\
\hline $200 \mathrm{U}$ & 52 & 52 & $0.37 \pm 0.06$ & $0.02 \pm 0.01$ & $0.19 \pm 0.01$ \\
\hline $\mathrm{U}_{\mathrm{NAT}} / \mathrm{U}_{\mathrm{TOT}}$ & 114 & 113 & $0.67 \pm 0.09$ & $<-0.01 \pm 0.02$ & $0.39 \pm 0.02$ \\
\hline
\end{tabular}


Table A.2. Summary of Radionuclide Concentrations in Columbia River Water at Priest Rapids Dam, 1980 Through 1989; Continuous Sampling System

\begin{tabular}{|c|c|c|c|c|c|c|}
\hline \multirow{2}{*}{\multicolumn{2}{|c|}{ Constituent }} & \multirow{2}{*}{$\begin{array}{l}\text { Total \# } \\
\text { Samples }\end{array}$} & \multirow{2}{*}{$\begin{array}{l}\text { \# Results } \\
>2 \text { Sig CE }\end{array}$} & \multicolumn{3}{|c|}{ Concentration, $\mathrm{pCi} / \mathrm{L}$} \\
\hline & & & & Maximum & Minimum & Average \\
\hline \multirow[t]{2}{*}{${ }^{60} \mathrm{Co}$} & $\mathbf{P}$ & 231 & 20 & $0.014 \pm 0.007$ & $-0.008 \pm 0.013$ & $0.0013 \pm 0.0003$ \\
\hline & $\mathbf{S}$ & 231 & 22 & $0.11 \pm 0.02$ & $-0.013 \pm 0.013$ & $0.0034 \pm 0.0012$ \\
\hline \multirow[t]{2}{*}{${ }^{134} \mathrm{Cs}$} & $\mathbf{P}$ & 216 & 27 & $0.02 \pm 0.01$ & $-0.008 \pm 0.007$ & $0.0012 \pm 0.0004$ \\
\hline & $\mathbf{S}$ & 215 & 34 & $0.02 \pm 0.01$ & $-0.013 \pm 0.024$ & $0.0028 \pm 0.0007$ \\
\hline \multirow[t]{2}{*}{${ }^{137} \mathrm{Cs}$} & $\mathbf{P}$ & 231 & 146 & $0.08 \pm 0.01$ & $-0.010 \pm 0.005$ & $0.0089 \pm 0.0016$ \\
\hline & $\mathbf{S}$ & 231 & 125 & $0.19 \pm 0.03$ & $-0.012 \pm 0.012$ & $0.018 \pm 0.003$ \\
\hline \multirow{4}{*}{$\begin{array}{l}{ }^{90} \mathrm{Sr} \\
{ }^{129} \mathrm{I} \\
{ }^{238} \mathrm{Pu}\end{array}$} & $\mathbf{S}$ & 11 & 11 & $0.26 \pm 0.02$ & $0.0056 \pm 0.0007$ & $0.08 \pm 0.06$ \\
\hline & $\mathbf{S}$ & 57 & 55 & $0.000045 \pm 0.000005$ & $0.0000016 \pm 0.0000004$ & $0.000009 \pm 0.000002$ \\
\hline & $\mathbf{P}$ & 41 & 16 & $0.00002 \pm 0.00000$ & $-0.000025 \pm 0.000009$ & $0.0000001 \pm 0.000002$ \\
\hline & $\mathbf{S}$ & 42 & 15 & $0.00046 \pm 0.00008$ & $-0.00017 \pm 0.00017$ & $0.000022 \pm 0.000030$ \\
\hline \multirow[t]{2}{*}{${ }^{209140} \mathrm{Pu}$} & $\mathbf{P}$ & 42 & 37 & $0.00034 \pm 0.00003$ & $0.000002 \pm 0.000007$ & $0.000045 \pm 0.000020$ \\
\hline & $\mathbf{S}$ & 42 & 21 & $0.0005 \pm 0.0012$ & $-0.000054 \pm 0.000033$ & $0.00012 \pm 0.00005$ \\
\hline \multicolumn{7}{|c|}{$\begin{array}{l}\mathbf{P}=\text { Particulate } \\
\mathbf{S}=\text { Soluble. }\end{array}$} \\
\hline
\end{tabular}


Table A.3. Summary of Radionuclide Concentrations in Columbia River Water at the 100-B Area, 1980 Through 1984; Composite Sampling System

\begin{tabular}{|c|c|c|c|c|c|}
\hline \multirow[b]{2}{*}{ Constituent } & \multirow{2}{*}{$\begin{array}{l}\text { Total \# } \\
\text { Samples }\end{array}$} & \multirow{2}{*}{$\begin{array}{l}\text { \# Results } \\
>2 \text { Sig CE }\end{array}$} & \multicolumn{3}{|c|}{ Concentration, $\mathrm{pCi} / \mathrm{L}$} \\
\hline & & & Maximum & Minimum & Average \\
\hline Total Alpha & 24 & 17 & $1.0 \pm 0.5$ & $0.07 \pm 0.26$ & $0.44 \pm 0.10$ \\
\hline Total Beta & 24 & 6 & $8.1 \pm 5.4$ & $-0.07 \pm 4.6$ & $3.1 \pm 1.0$ \\
\hline Gamma Scan & & & & & \\
\hline${ }^{\infty} \mathrm{Co}$ & 23 & 2 & $1.4 \pm 1.9$ & $-0.9 \pm 1.6$ & $0.23 \pm 0.20$ \\
\hline${ }^{65} \mathrm{Zn}$ & 22 & 2 & $4.5 \pm 7.1$ & $-2.7 \pm 2.9$ & $-0.04 \pm 0.64$ \\
\hline${ }^{106} \mathrm{Ru}$ & 10 & 1 & $9.4 \pm 5.4$ & $-7.9 \pm 9.2$ & $-1.4 \pm 3.2$ \\
\hline${ }^{137} \mathrm{Cs}$ & 23 & 3 & $2.5 \pm 3.6$ & $-8.3 \pm 1.0$ & $0.26 \pm 0.28$ \\
\hline${ }^{144} \mathrm{CePr}$ & 9 & 0 & $5.3 \pm 16.0$ & $-15 \pm 13$ & $-3.2 \pm 3.8$ \\
\hline${ }^{3} \mathbf{H}$ & 24 & 15 & $417 \pm 150$ & $-240 \pm 414$ & $190 \pm 64$ \\
\hline${ }^{r} \mathrm{Sr}$ & 11 & 4 & $0.21 \pm 0.19$ & $-0.09 \pm 0.14$ & $0.09 \pm 0.05$ \\
\hline${ }^{9} \mathrm{Sr}$ & 15 & 14 & $0.40 \pm 0.06$ & $0.14 \pm 0.26$ & $0.24 \pm 0.04$ \\
\hline $\mathrm{U}_{\mathrm{MAT}}$ & 18 & 18 & $0.63 \pm 0.22$ & $0.12 \pm 0.04$ & $0.40 \pm 0.06$ \\
\hline
\end{tabular}


Table A.4. Summary of Tritium ( $\mathrm{H}$ ) and Iodine-129 $\left({ }^{(20} \mathrm{I}\right)$ Concentrations in Columbia River Water at the Old Hanford Townsite, 1982

\begin{tabular}{|c|c|c|c|c|c|}
\hline \multirow[b]{2}{*}{ Constituent } & \multirow{2}{*}{$\begin{array}{c}\text { Total \# } \\
\text { Samples }\end{array}$} & \multirow{2}{*}{$\begin{array}{c}\text { \# Results } \\
\text { >2 Sig CE }\end{array}$} & \multicolumn{3}{|c|}{ Concentration, $\mathrm{pCi} / \mathrm{L}$} \\
\hline & & & Maximum & Minimum & Average \\
\hline${ }^{3} \mathrm{H}$ & 18 & 18 & $332 \pm 20$ & $108 \pm 16$ & $178 \pm 37$ \\
\hline${ }^{129} \mathbf{I}$ & 12 & 11 & $0.000008 \pm 0.000001$ & $<0.000003 \pm 0.00006$ & $0.000005 \pm .0 .000001$ \\
\hline
\end{tabular}


Table A.5. Summary of Radionuclide Concentrations in Columbia River Water at the 300 Area, 1980 Through 1989; Composite Sampling System

\begin{tabular}{|c|c|c|c|c|c|}
\hline \multirow[b]{2}{*}{ Constituent } & \multirow{2}{*}{$\begin{array}{c}\text { Total \# } \\
\text { Samples }\end{array}$} & \multirow{2}{*}{$\begin{array}{l}\text { \# Results } \\
>2 \text { Sig CE }\end{array}$} & \multicolumn{3}{|c|}{ Concentration, $\mathrm{pCi} / \mathrm{L}$} \\
\hline & & & Maximum & Minimum & Average \\
\hline Total Alpha & 51 & 43 & $1.4 \pm 1.0$ & $0.2 \pm 0.3$ & $0.6 \pm 0.1$ \\
\hline Total Beta & 51 & 18 & $6.3 \pm 5.2$ & $-2.4 \pm 5.3$ & $2.1 \pm 0.5$ \\
\hline Gamma Scan & & & & & \\
\hline${ }^{60} \mathrm{Co}$ & 41 & 9 & $9.3 \pm 18.0$ & $-1.1 \pm 1.2$ & $0.36 \pm 0.48$ \\
\hline${ }^{65} \mathrm{Zn}$ & 41 & 2 & $1.5 \pm 2.7$ & $-4.3 \pm 28.0$ & $-0.45 \pm 0.45$ \\
\hline${ }^{106} \mathrm{Ru}$ & 28 & 2 & $6.4 \pm 6.9$ & $-8.3 \pm 11.0$ & $1.21 \pm 1.59$ \\
\hline${ }^{137} \mathrm{Cs}$ & 41 & 3 & $7.1 \pm 15.0$ & $-1.4 \pm 2.7$ & $0.24 \pm 0.41$ \\
\hline${ }^{14} \mathrm{CePr}$ & 24 & 0 & $16.1 \pm 31.3$ & $-21.0 \pm 15.9$ & $-1.85 \pm 2.70$ \\
\hline${ }^{3} \mathrm{H}$ & 43 & 33 & $1570 \pm 293$ & $-90 \pm 419$ & $246 \pm 73$ \\
\hline${ }^{89} \mathrm{Sr}$ & 31 & 9 & $0.25 \pm 0.30$ & $-0.26 \pm 0.29$ & $0.06 \pm 0.04$ \\
\hline${ }^{90} \mathrm{Sr}$ & 43 & 43 & $0.75 \pm 0.06$ & $0.07 \pm 0.04$ & $0.21 \pm 0.04$ \\
\hline${ }^{204} \mathrm{U}$ & 16 & 16 & $0.44 \pm 0.07$ & $0.21 \pm 0.05$ & $0.30 \pm 0.03$ \\
\hline${ }^{235} \mathrm{U}$ & 16 & 4 & $0.04 \pm 0.02$ & $-0.005 \pm 0.006$ & $0.010 \pm 0.005$ \\
\hline $288 \mathrm{U}$ & 16 & 16 & $0.30 \pm 0.05$ & $0.16 \pm 0.04$ & $0.24 \pm 0.02$ \\
\hline $\mathrm{U}_{\mathrm{NAT}} / \mathrm{U}_{\mathrm{TOT}}$ & 30 & 30 & $0.77 \pm 0.09$ & $0.37 \pm 0.13$ & $0.53 \pm 0.04$ \\
\hline
\end{tabular}


Table A.6. Summary of Radionuclide Concentrations in Columbia River Water at the 300 Area, 1980 Through 1989; Continuous Sampling System

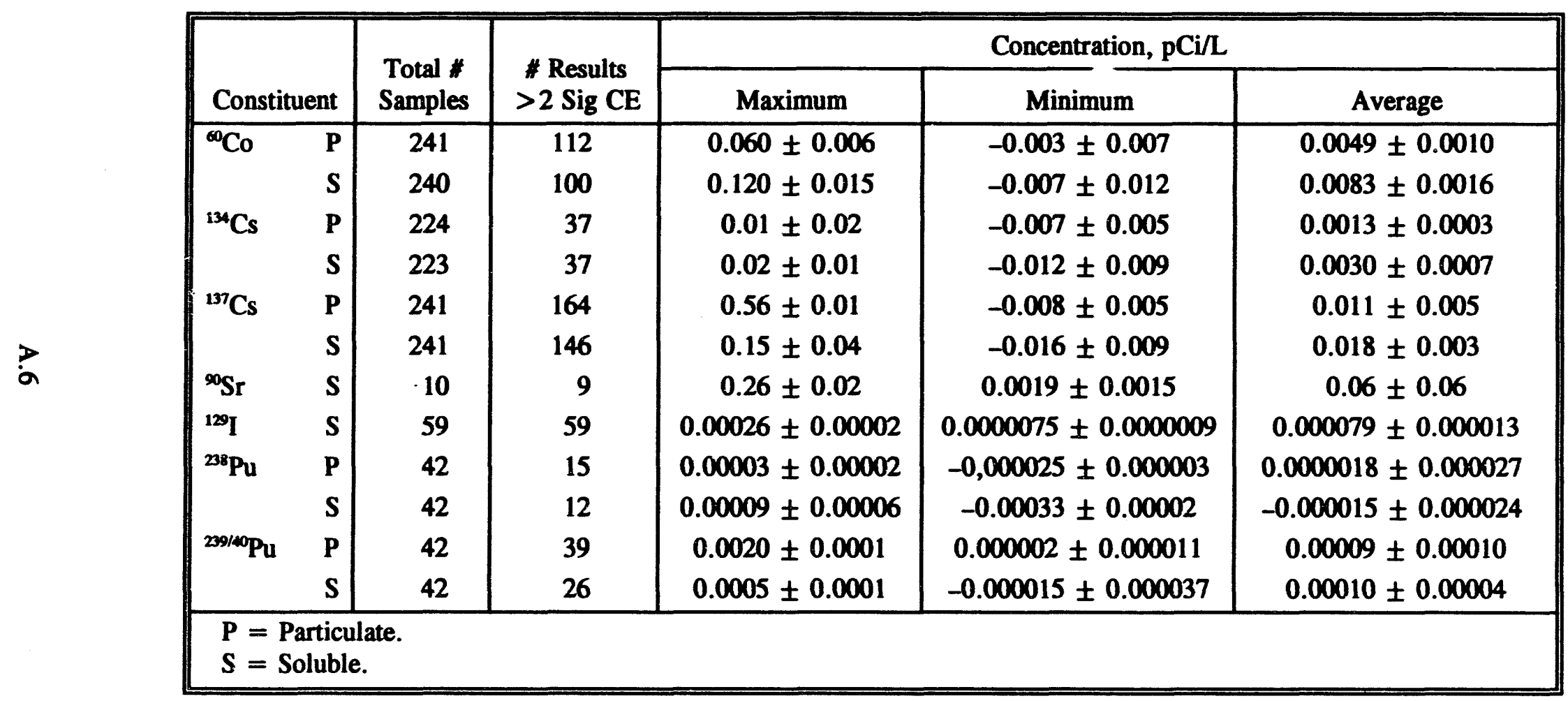


Table A.7. Summary of Radionuclide Concentrations in Columbia River Water at the Richland Pumphouse, 1980 Through 1989; Composite Sampling System

\begin{tabular}{|c|c|c|c|c|c|}
\hline \multirow[b]{2}{*}{ Constituent } & \multirow{2}{*}{$\begin{array}{c}\text { Total \# } \\
\text { Samples }\end{array}$} & \multirow{2}{*}{$\begin{array}{c}\text { \# Results } \\
>2 \text { Sig CE }\end{array}$} & \multicolumn{3}{|c|}{ Concentration, $\mathrm{pCi} / \mathrm{L}$} \\
\hline & & & Maximum & Minimum & Average \\
\hline Total Alpha & 122 & 82 & $1.3 \pm 1.1$ & $-0.04 \pm 0.23$ & $0.5 \pm 0.1$ \\
\hline Total Beta & 122 & 47 & $107 \pm 5.5$ & $-2.5 \pm 5.1$ & $2.1 \pm 0.3$ \\
\hline Gamma Scan & & & & & \\
\hline${ }^{60} \mathrm{Co}$ & 122 & 19 & $3.7 \pm 18.0$ & $-4.8 \pm 8.5$ & $0.14 \pm 0.14$ \\
\hline${ }^{6} \mathrm{Zn}$ & 122 & 16 & $23.5 \pm 28.0$ & $-9.9 \pm 28.0$ & $-0.01 \pm 0.51$ \\
\hline${ }^{106} \mathrm{Ru}$ & 90 & 12 & $14.3 \pm 7.2$ & $-18.3 \pm 47.3$ & $-0.40 \pm 1.11$ \\
\hline${ }^{137} \mathrm{Cs}$ & 122 & 18 & $2.4 \pm 15.0$ & $-1.9 \pm 1.2$ & $0.13 \pm 0.10$ \\
\hline${ }^{144} \mathrm{CePr}$ & 89 & 2 & $37.8 \pm 60.9$ & $-11.2 \pm 10.1$ & $0.17 \pm 1.23$ \\
\hline${ }^{3} \mathrm{H}$ & 128 & 128 & $668 \pm 22$ & $39 \pm 12$ & $170 \pm 14$ \\
\hline${ }^{89} \mathrm{Sr}$ & 106 & 28 & $0.9 \pm 0.3$ & $-0.02 \pm 0.01$ & $0.07 \pm 0.03$ \\
\hline${ }^{90} \mathrm{Sr}$ & 106 & 102 & $1.00 \pm 0.07$ & $0.009 \pm 0.063$ & $0.16 \pm 0.02$ \\
\hline${ }^{204} \mathrm{U}$ & 52 & 52 & $0.45 \pm 0.06$ & $0.02 \pm 0.01$ & $0.25 \pm 0.02$ \\
\hline${ }^{235} \mathrm{U}$ & 52 & 20 & $0.04 \pm 0.02$ & $-0.005 \pm 0.00$ & $0.010 \pm 0.003$ \\
\hline${ }^{238} \mathrm{U}$ & 52 & 52 & $0.36 \pm 0.05$ & $0.03 \pm 0.01$ & $0.21 \pm 0.03$ \\
\hline $\mathrm{U}_{\mathrm{NAT}} / \mathrm{U}_{\mathrm{TOT}}$ & 126 & 124 & $1.04 \pm 0.37$ & $0.01 \pm 0.02$ & $0.46 \pm 0.03$ \\
\hline
\end{tabular}


Table A.8. Summary of Radionuclide Concentrations in Columbia River Water at the Richland Pumphouse, 1987 Through 1989; Continuous Sampling System

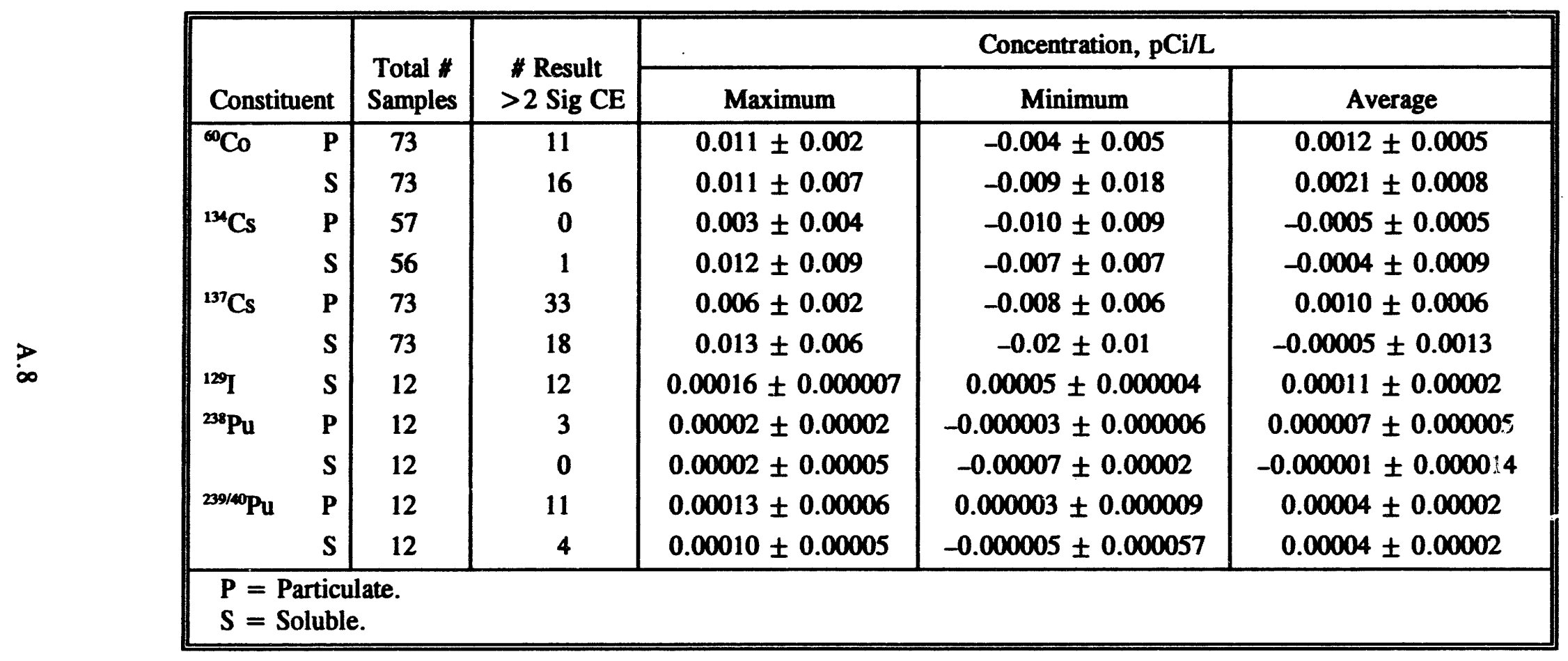


Table A.9. Annual Average Total Alpha Concentrations in Columbia River Water at Priest Rapids Dam, the 300 Area, and the Richland Pumphouse, 1980 Through 1989

\begin{tabular}{||c|c|c|c||}
\hline \multirow{3}{*}{ Year } & \multicolumn{3}{|c||}{ Concentration, $\mathrm{pCi} / \mathrm{L}$} \\
\cline { 2 - 4 } & Priest Rapids & 300 Area & Richland Pumphouse \\
\hline 1980 & $0.4 \pm 0.1^{(\mathrm{o})}$ & $0.5 \pm 0.1$ & $0.5 \pm 0.1$ \\
1981 & $0.4 \pm 0.1$ & $0.6 \pm 0.1$ & $0.4 \pm 0.1$ \\
1982 & $0.4 \pm 0.2$ & $0.5 \pm 0.1$ & $0.4 \pm 0.1$ \\
1983 & $0.3 \pm 0.1$ & $0.7 \pm 0.3$ & $0.5 \pm 0.1$ \\
1984 & $0.5 \pm 0.1$ & $0.4 \pm 0.2$ & $0.6 \pm 0.1$ \\
1985 & $0.4 \pm 0.2$ & $0.8 \pm 0.3$ & $0.6 \pm 0.2$ \\
1986 & $0.5 \pm 0.1$ & $0.7 \pm 0.2$ & $0.6 \pm 0.1$ \\
1987 & $0.4 \pm 0.1$ & $0.6 \pm 0.2$ & $0.5 \pm 0.2$ \\
1988 & $0.3 \pm 0.2$ & $0.5 \pm 0.2$ & $0.3 \pm 0.1$ \\
1989 & $0.7 \pm 0.2$ & $1.0 \pm 0.3$ & $0.6 \pm 0.2$ \\
\hline (a) 100-B sample location.
\end{tabular}

Table A.10. Annual Average Total Beta Concentrations in Columbia River Water at Priest Rapids Dam, the 300 Area, and the Richland Pumphouse, 1980 Through 1989

\begin{tabular}{||l|l|l|c||}
\hline \multirow{2}{*}{ Year } & \multicolumn{3}{|c|}{ Concentration, pCi/L } \\
\cline { 2 - 4 } & Priest Rapids & 300 Area & Richland Pumphouse \\
\hline 1980 & $3.0 \pm 1.4^{(a)}$ & $3.3 \pm 0.9$ & $2.6 \pm 1.6$ \\
1981 & $1.9 \pm 1.4$ & $2.2 \pm 1.2$ & $2.3 \pm 1.3$ \\
1982 & $3.1 \pm 1.2$ & $3.4 \pm 2.9$ & $3.2 \pm 1.4$ \\
1983 & $6.1 \pm 5.9(b)$ & $4.2 \pm 1.8$ & $3.7 \pm 1.4$ \\
1984 & $1.8 \pm 0.6$ & $1.6 \pm 1.0$ & $2.2 \pm 0.5$ \\
1985 & $1.5 \pm 0.3$ & $1.1 \pm 0.4$ & $1.5 \pm 0.4$ \\
1986 & $1.9 \pm 0.4$ & $1.6 \pm 1.0$ & $1.6 \pm 0.4$ \\
1987 & $0.9 \pm 0.4$ & $2.1 \pm 0.6$ & $1.1 \pm 0.4$ \\
1988 & $1.0 \pm 0.4$ & $1.0 \pm 0.5$ & $0.9 \pm 0.3$ \\
1989 & $1.5 \pm 0.7$ & $1.0 \pm 1.5$ & $1.3 \pm 0.4$ \\
\hline (a) 100-B sample location. \\
(b) One high result.
\end{tabular}


Table A.11. Annual Average Tritium $\left({ }^{3} \mathrm{H}\right)$ Concentrations in Columbia River Water at Priest Rapids Dam, the 300 Area, and the Richland Pumphouse, 1980 Through 1989

\begin{tabular}{||l|l|c|c||}
\hline \multirow{2}{*}{ Year } & \multicolumn{3}{|c|}{ Concentration, pCi/L } \\
\cline { 2 - 4 } & Priest Rapids & 300 Area & Richland Pumphouse \\
\hline 1980 & $266 \pm 77^{(\text {) }}$ & $284 \pm 134$ & $265 \pm 66$ \\
1981 & $167 \pm 31$ & $330 \pm 133$ & $199 \pm 31$ \\
1982 & $159 \pm 38$ & $219 \pm 216$ & $216 \pm 61$ \\
1983 & $103 \pm 25$ & $550 \pm 684^{(b)}$ & $135 \pm 28$ \\
1984 & $127 \pm 15$ & $230 \pm 134$ & $169 \pm 22$ \\
1985 & $112 \pm 17$ & $152 \pm 103$ & $152 \pm 21$ \\
1986 & $98 \pm 12$ & $198 \pm 45$ & $149 \pm 18$ \\
1987 & $73 \pm 10$ & $165 \pm 31$ & $128 \pm 15$ \\
1988 & $70 \pm 6$ & $176 \pm 58$ & $132 \pm 10$ \\
1989 & $63 \pm 5$ & $161 \pm 35$ & $129 \pm 18$ \\
\hline (a) $100-B$ sample location. \\
(b) Influenced by a single elevated result. \\
\hline
\end{tabular}

Table A.12. Annual Average Strontium-90 ( $\left.{ }^{9} \mathrm{Sr}\right)$ Concentrations ir. Columbia River Water at Priest Rapids Dam, the 300 Area, and the Richland Pumphouse, 1980 Through 1989

\begin{tabular}{||c|c|c|c||}
\hline \multirow{2}{*}{ Year } & \multicolumn{3}{|c|}{ Concentration, pCi/L } \\
\cline { 2 - 4 } & Priest Rapids & 300 Area & Richland Pumphouse \\
\hline 1980 & $0.24 \pm 0.08^{(a)}$ & $0.29 \pm 0.12$ & $0.20 \pm 0.02$ \\
1981 & $0.15 \pm 0.02$ & $0.25 \pm 0.03$ & $0.23 \pm 0.04$ \\
1982 & $0.18 \pm 0.05$ & $0.19 \pm 0.05$ & $0.17 \pm 0.06$ \\
1983 & $0.18 \pm 0.06$ & $0.23 \pm 0.03$ & $0.29 \pm 0.14$ \\
1984 & $0.14 \pm 0.02$ & $0.36 \pm 0.20$ & $0.17 \pm 0.04$ \\
1985 & $0.15 \pm 0.02$ & $0.21 \pm 0.02$ & $0.16 \pm 0.03$ \\
1986 & $0.15 \pm 0.01$ & $0.16 \pm 0.08$ & $0.16 \pm 0.02$ \\
1987 & $0.14 \pm 0.01$ & $0.13 \pm 0.03$ & $0.13 \pm 0.02$ \\
1988 & $0.10 \pm 0.02$ & $0.12 \pm 0.02$ & $0.12 \pm 0.02$ \\
1989 & $0.08 \pm 0.01$ & $0.09 \pm 0.02$ & $0.07 \pm 0.01$ \\
\hline (a) 100-B sample location.
\end{tabular}


Table A.13. Annual Average Uranium Concentrations in Columbia River Water at Priest Rapids Dam, the 300 Area, and the Richland Pumphouse, 1980 Through 1989

\begin{tabular}{||c|c|c|c||}
\hline \multirow{2}{*}{ Year } & \multicolumn{3}{|c||}{ Concentration, pCi/L } \\
\cline { 2 - 4 } & Priest Rapids & 300 Area & Richland Pumphouse \\
\hline 1980 & $0.40 \pm 0.06^{(\mathbf{a})}$ & $\mathrm{NA}^{(\mathrm{b})}$ & $0.54 \pm 0.08$ \\
1981 & $0.37 \pm 0.10$ & $0.48 \pm 0.12$ & $0.42 \pm 0.05$ \\
1982 & $0.36 \pm 0.07$ & $0.57 \pm 0.15$ & $0.38 \pm 0.06$ \\
1983 & $0.27 \pm 0.07$ & $0.51 \pm 0.04$ & $0.50 \pm 0.14$ \\
1984 & $0.33 \pm 0.04$ & $\mathrm{NA}^{(\mathrm{o})}$ & $0.45 \pm 0.08$ \\
1985 & $0.38 \pm 0.10$ & $0.51 \pm 0.01$ & $0.48 \pm 0.07$ \\
1986 & $0.45 \pm 0.10$ & $0.55 \pm 0.10$ & $0.50 \pm 0.10$ \\
1987 & $0.46 \pm 0.03$ & $0.56 \pm 0.05$ & $0.51 \pm 0.08$ \\
1988 & $0.37 \pm 0.04$ & $0.48 \pm 0.07$ & $0.41 \pm 0.07$ \\
1989 & $0.46 \pm 0.03$ & $0.57 \pm 0.16$ & $0.44 \pm 0.03$ \\
\hline (a) 100-B sample location. \\
(b) NA - not analyzed. \\
(c) Uranium analysis changed from $\mathrm{U}_{\mathrm{NAT}}$ to U-isotopic. \\
\hline
\end{tabular}

Table A.14. Annual Average Iodine-129 $\left({ }^{129} \mathrm{~T}\right)$ Concentrations in Columbia River Water at Priest Rapids Dam, the 300 Area, and the Richland Pumphouse, 1980 Through 1989

\begin{tabular}{||c|c|c|c||}
\hline \multirow{2}{*}{ Year } & \multicolumn{3}{|c|}{ Concentration, pCi/L } \\
\cline { 2 - 4 } & Priest Rapids & 300 Area & Richland Pumphouse \\
\hline 1980 & $0.000006 \pm 0.000001$ & $0.000050 \pm 0.000024$ & NS \\
1981 & $0.000006 \pm 0.000001$ & $0.000050 \pm 0.000021$ & NS \\
1982 & $0.000006 \pm 0.000002$ & $0.000069 \pm 0.000034$ & NS \\
1983 & $0.000021 \pm 0.000010$ & $0.000073 \pm 0.000026$ & NS \\
1984 & $0.000012 \pm 0.000004$ & $0.000077 \pm 0.000034$ & NS \\
1985 & $0.000009 \pm 0.000005$ & $0.000088 \pm 0.000043$ & NS \\
1986 & $0.000009 \pm 0.000001$ & $0.00010 \pm 0.00004$ & NS \\
1987 & $0.000007 \pm 0.000004$ & $0.00011 \pm 0.00002$ & $0.00010 \pm 0.00002$ \\
1988 & $0.000017 \pm 0.000019$ & $0.000091 \pm 0.000028$ & $0.00010 \pm 0.00003$ \\
1989 & $0.000005 \pm 0.000001$ & $0.00017 \pm 0.00009$ & $0.00012 \pm 0.00005$ \\
\hline NS - not sampled.
\end{tabular}




\section{Distribution}

No. of

Copies

\section{OFESITE}

2 DOE/Office of Scientific and Technical Information

J. Erickson

Washington State Department of Health

Division of Radiation

Protection

Airdustrial Center

Building 5, M.S. C-13

Olympia, WA 98503

R. Jim

Environmental Restoration/

Waste Management

Yakima Indian Nation

P.O. Box 151

Toppenish, WA 98948

R. George

Environmental Planning/

Rights Protection

Confederated Tribes of the

Umatilla Indian Reservation

P.O. Box 638

Pendleton, OR 97801

D. Powaukee

Environmental Restoration/

Waste Management

Nez Perce Tribe

P.O. Box 365

Lapwai, ID 83540-0365

J. R. Wilkinson

Confederated Tribes of the Umatilla Indian Reservation

P.O. Box 638

Pendleton, OR 97801
No. of

Copies

A. Childs

Confederated Tribes of the

Umatilla Indian Reservation

P.O. Box 638

Pendleton, OR 97801

S. Cross

Washington State Department of Ecology

P.O. Box 57600

Olympia, WA $98504-7600$

L. E. Gadbois

U.S. Environmental Protection Agency

712 Swift, MS B5-01

Richland, WA 99352

\section{ONSITE}

4 DOE Richland Operations Office
B. L. Foley
P7-65
E. D. Goller
A5-19
J. B. Hall
A5-55
K. M. Thompson
A5-15

7 Westinghouse Hanford Company

J. J. Dorian

H6-30

L. C. Hulstrom

H6-30

C. J. Perkins

$\mathrm{X} 0-21$

J. W. Schmidt

H6-30

S. E. Vukelich

H6-02

S. G. Weiss

H6-02

Public Reading Room

49 Pacific Northwest Laboratory

E. J. Antonio

K6-61

R. W. Bryce

K6-96

A. T. Cooper

T5-12

M. K. DeSmet

K6-62

Dist.1 
No. of

Copies

R. L. Dirkes (25)

R. H. Gray

R. W. Hanf, Jr.

R. E. Jaquish

R. E. Lundgren

E. W. Lusty

G. W. Patton

T. M. Poston

H. E. Westerdahl (3)

R. K. Woodruff

Publishing Coordination

SESP Historical Files/

R. K. Woodruff (2)

Technical Report Files (5)
No. of

Copies

K6-61

K1-33

K6-61

K1-30

K6-62

K6-79

K6-63

K6-61

K6-60

$\mathrm{K} 6-61$
Routing
R. M. Ecker
Sequim
M. J. Graham
K1-69
P. M. Irving
K6-98
C. S. Sloane
K6-04
P. C. Hays (last)
K6-86 

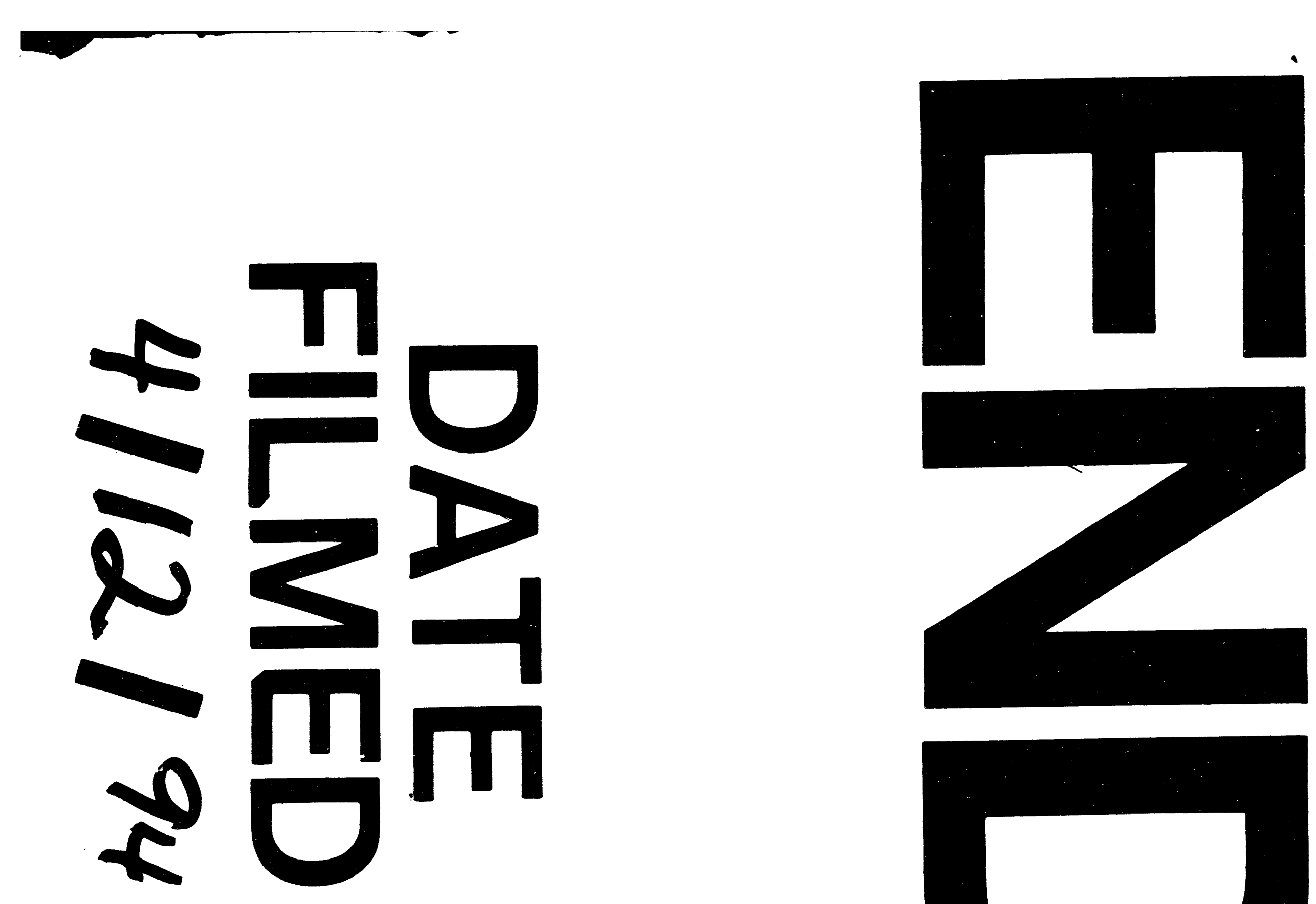
